\title{
Soğuk Savaş Sürecinde Komünizme Karşı Türkiye'nin Uluslararası Güvenlik ve Savunma İşbirlikleri Kurma Çabaları: Balkan Paktı ve İttifakı
}

\section{Turkey's Efforts to Establish International Security and Defense Pacts against Communism in the Cold War Era: Balkan Pact and Alliance}

\section{Ceyda TUNA KOCAOĞLU*}

\begin{abstract}
$\ddot{O} z$
II. Dünya Savaşı sonuçları itibariyle 20. yüzyılın en önemli olaylarından biri olmuştur. Savaşın yıkıcı etkisi, başta Almanya olmak üzere hemen bütün Avrupa şehirlerinde kendini göstermiştir. Milyonlarca insanın hayatını kaybettiği savaşta savaşan tarafların tamamı zarar görmüş̧ür. Bununla birlikte II. Dünya Savaşı sadece yıkıcı etkisiyle değil, aynı zamanda savaş sonrasının uluslararası ilişkiler alanında neden olduğu köklü değişiklikler bakımından da büyük önem taşımaktadır. Savaştan hemen sonra uluslararast ilişsiler ideolojik temelde yeniden düzenlenerek bir yanda ABD'nin başını çektiği kapitalist devletler ile diğer yanda Sovyetler Birliği'nin başını çektiği komünist devletler arasında yürütülen ve Soğuk Savaş adı verilen bir mücadele alanına dönüşmüşür. Savaştan sonra Sovyetler Birliği'nin komünizmi tüm dünyada hâkim kılma eğilimi ve bu çerçevede yürüttüğü yayılmacı politika başta Batıl kapitalist devletler olmak üzere ABD'yi derin bir endişeye
\end{abstract}

\footnotetext{
* Dr. Öğr. Üyesi, Bandırma Onyedi Eylül Üniversitesi, Manyas Meslek Yüksek Okulu Medya ve İletişim Program1, ORCID: 0000-0001-6537-1804, e-posta: ckocaoglu@ bandirma.edu.tr.
}

Geliş Tarihi / Submitted: 10.01.2021

Kabul Tarihi / Accepted: 02.03.2021 


\section{Ceyda TUNA KOCAOĞLU}

2

Güvenlik

Stratejileri

Cilt: 17

Sayı: 37

sevk etmiştir. $B u$ nedenle $A B D$ tarafindan başlatılan komünizmle mücadele kisa sürede tüm dünyada karşllık bulacak bu arada Sovyet komünizminin yakın tehdidi altında bulunan bölgelerde ABD'nin de teşviki ve telkiniyle önemli gelişmelere neden olacaktır. Bu çerçevede komünizm tehlikesiyle doğrudan yüzleşmek zorunda kalan Balkanlar, Türkiye ve Orta Doğu gibi stratejik açıdan önemli coğrafyalarda güvenlik ve savunma sorunu bu bölgelerdeki devletlerin bazı işbirliği çabaları içine girmelerine zemin hazırlayacaktır. Bu kapsamda Türkiye Sovyet komünizminin yakın tehdidi altında bulunan ve bundan dolayı savaş sonrasında ABD'nin başını çektiği Batı bloğu yanında tavır koyan bir ülke olarak 1952 yllında NATO'ya üye olduktan sonra komünizm karşısında bir güvenlik ve savunma alanı oluşturma gayretlerine girmiştir. Bu çerçevede Türkiye'nin yoğun çaba ve gayretleri sonucunda Türkiye, Yunanistan ve Yugoslavya arasinda önce 28 Şubat 1953 'te Balkan Paktı kurulmus ve hemen bir yll sonra da 9 Ağustos 1954 tarihinde yine Türkiye'nin çabalartyla bu pakt Balkan İttifakı ile bir askerî savunma antlaşmasına dönüş̧ürülerek komünizm tehlikesine karşı Türkiye'nin öncülügünde önemli bir işbirliği gerçekleştirilmiştir.

Anahtar kelimeler: Balkan Paktl, Balkan İttifakl, Soğuk Savaş, Komünizm, Güvenlik.

\section{Abstract}

The Second World War, with regard to its consequences, was one of the most important developments of the 20th century. The devastating effect of the war manifested itself in almost all European cities, particularly in Germany. Millions lost their lives in this war and all belligerents suffered from it. On the other hand, the Second World War is of great importance not only for the destruction it caused but also for the radical changes it brought along in the international relations. Immediately after the war, international relations were rearranged on an ideological basis. Consequently, international relations turned into a confrontation zone where capitalist states led by the United States and communist states led by the Soviet Union clashed. The Soviet efforts to spread communism worldwide and the policies it pursued to this end caused a deep concern in the capitalist states, primarily in the USA. 
Soğuk Savaş Sürecinde Komünizme Karşı Türkiye'nin Uluslararası Güvenlik ve Savunma İşbirlikleri Kurma Çabaları: Balkan Paktı ve İttifakı

Therefore, the struggle against communism initiated by the USA shortly grew worldwide and resulted in significant developments in regions close to the communism sphere thanks to the American incentive. Thus, the security and defense problem in strategically important regions such as the Balkans, the Middle East and Turkey necessitated the search for cooperation. In this regard, Turkey, as a state located close to the communism threat, took its position by the Western Powers led by the USA and became a member of the NATO in 1952. Accordingly, Turkey initiated its efforts to build a security and defense zone against communism. As a result, thanks to the intense efforts of Turkey, the Balkan Pact was formed on 28 February 1953 with the participation of Turkey, Greece and Yugoslavia. One year later, the pact was transformed into the Balkan Alliance, a military defense treaty, on 9 August 1954 as a result of Turkish efforts, establishing an important cooperation against the communist threat. Security.

Keywords: Balkan Pact, Balkan Alliance, Cold War, Communism,

\section{Giriș}

İkinci Dünya Savaşı öncekinden çok daha yıkıcı oldu. 1945 yılının son yarısında savaş sona erdiğinde geride zarar görmemiş çok az yerleşim birimi ile adeta harabeye çevrilmiş bir Avrupa kalmıştı. Yakılmış yıkılmış şehirler, evsiz barksız açlık ve sefalet içinde kalmış milyonlarca insan Avrupa'nın dramatik durumunu ortaya koyuyordu. ${ }^{1}$ Sadece Avrupa değil Asya'nın önemli devleti Rusya da her ne kadar savaş boyunca Orta ve Doğu Avrupa'da etkin bir biçimde yayılmış

\footnotetext{
${ }^{1}$ II. Dünya Savaşı sonrasında Avrupa'nın genel durumu için bkz: Tony Judt, Savaş Sonrast: 1945 Sonrası Avrupa Tarihi, Yap1 Kredi Yayınları, İstanbul, 2009; I Ian Buruma, Sıfır Yılı (1945'in Tarihi), Çev: Nurettin Elhüseyni, Yapı Kredi Yayınları, İstanbul, 2013.; J. M. Roberts, Avrupa Tarihi, (Çev: Fethi Aytuna), İnkılap yayınları, İstanbul, 2015.; J. M. Roberts, Yirminci Yüzyıl Tarihi, (Çev: Sinem Gül), Dost Yayınları, Ankara, 2003.
} 


\section{4}

Güvenlik Stratejileri

Cilt: 17

Say1: 37

olsa da savaşın tüm yıkımından büyük ölçüde payını almıştı. II. Dünya Savaşı sonucunda Sovyet Rusya, neredeyse yenilgiye uğrattığ düşmanı Almanya kadar kötü bir haldeydi. Ülke çok kayıp vermiş ve iktisadi altyapısının büyük bir bölümü Alman işgali sırasında tahrip edilmişti. Stalin, halkını savaşa seferber etmek için savaş sırasında iç politikasında ideolojik saflığı korumayı bir kenara bırakmak zorunda olduğunu anlamıştı. Savaş sonrası dönemde ise Sovyet rejiminin daha iyi yaşam standartları sağlayamaması durumunda halkın geçmiş yıllarda yaptığı fedakârlıkların boşa gittiğini düşünmemesini bekleyemezdi. Ayrıca Avrupa kıtasında zamanın en büyük ordusu olan Kızıl Ordu da savaş sonrası kalkınma çabalarının başlaması için er veya geç terhis edilecekti. Sovyetlerin savaş sonrasında ülkelerini yeniden inşa etmeleri için güvenlik garantilerine ilaveten para ve malzeme yardımına ihtiyaçları vard1. ${ }^{2}$ Kısacası savaş savaşan tüm tarafların yıkımına da neden olmuştu.

II. Dünya Savaşı bu yıkıcı sonuçlarının yanında uluslararası ortamın farklı paradigmalar etrafinda yeniden şekillenmesinde de önemli rol oynadı. Uluslararası politika alanında ilk defa ideoloji en temel belirleyici faktör haline geldi. 19. yüzyılın önemli ideolojilerinden sosyalizm 20. Yüzyılın ilk çeyreğinde Rusya'da Çarlık rejimine son vererek iktidara gelmiş ve Stalin'in "tek ülkede sosyalizm" anlayışı çerçevesinde II. Dünya Savaşına kadar tüm Rusya'da hâkim ideoloji olmayı başarmıştı. II. Dünya Savaşı ise Sovyet komünizminin Rusya dışındaki coğrafyalarda da yayılmasının önünü açmıştır. Savaş boyunca, aynı birliktelik içerisinde yer aldığı Amerika Birleşik Devletleri'nin de bilgisi, belki de Roosevelt'in politik hesapları nedeniyle, Sovyet komünizmi özellikle Orta ve Doğu Avrupa'da hissedilir biçimde yayılma göstermiştir. II. Dünya Savaşı'na kadar daha çok eski Rus imparatorluğunun topraklarıyla sınırlı kalmış olan Sovyet yayılması, savaşla birlikte genişleme imkânı bulmuştur. Sovyetler birliği 1939 yılından itibaren, savaşı firsat bilerek, 1945'e kadar, yaklaşık dokuz ülkeyi Sovyet hâkimiyet alanı içine dâhil

\footnotetext{
${ }^{2}$ Antony Best, Jussi M. Hanhimaki, Joseph A. Maiolo, Kirsten E. Schulze, 20.Yüzyılın Uluslararası Tarihi, (Çev: Taciser Ulaş Belge), Siyasal Kitabevi, Ankara, 2012, s. 244.
} 
Soğuk Savaş Sürecinde Komünizme Karşı Türkiye'nin Uluslararası Güvenlik ve Savunma İşbirlikleri Kurma Çabaları: Balkan Paktı ve İttifakı

etmiştir. Fin Karalia'nın bir bölümünden başka, Estonya, Letonya ve Litvanya'nın tamamını, Polonya'dan Curzon'un doğu bölgelerini içeren hat boyunu, Çekoslovakya'dan Rutenya'yı, Almanya'dan Konigsberg limanın1, Romanya'dan Besarabya ve Bukovina'y1 ve Japonya'dan Güney Shalin ve Kuriles'i alarak savaşta topraklarına toprak katmıştır. ${ }^{3}$ Sovyetler Birliği ayrıca, II. Dünya Savaşı münasebetiyle, Polonya, Çekoslovakya, Macaristan, Bulgaristan, Romanya, Hirvatistan, Kuzey İran ve Mançurya'da nerdeyse tüm ekonomik ve siyasi yönetim gücünü de ele geçirmiş ve işgali altında bulundurduğu Alman topraklarında ise Sovyet ekonomik modelini başarıyla yerleştirmiştir. ${ }^{4}$ Savaş esnasındaki bu gelişmeler her ne kadar Roosevelt'in temkinli Sovyet politikasından dolayı çok fazla dikkate alınmamış, hatta zaman zaman görmezden gelinmişti. Ancak savaş bittiğinde Amerikan dış politikası yavaş yavaş Sovyet gerçeğini ve gelecekte nasıl bir tehlike haline dönüşebileceğinin farkına varmaya başladı. Çünkü Sovyetler Birliği II. Dünya Savaşı ve hemen sonrasında komünist ideolojiyi tüm dünyada hâkim kılmak amacıyla özellikle üç yönde yayılma faaliyetine girmiştir. Bunlar, Avrupa, Orta Doğu ve Asya-Uzak Doğu'ydu. ${ }^{5}$

Savaş sonrası Sovyet komünizminin tüm dünyayı tehdit ettiği gerçeğinin başta Batı Avrupa devletleri olmak üzere hemen sonrasında Amerika Birleşik Devletleri tarafından kesin bir biçimde kabul edilmesi uluslararası ortamın yeniden şekillenmesine neden olmuştur. Öncelikle Batı Avrupa'nın olmak üzere tüm dünyanın güvenliği uluslararası politikanın en temel sorunu haline gelmiştir. Sovyet komünizminin öncelikli tehdit alanı Batı Avrupa, Balkanlar ve güney sahasındaki Türkiye, Yunanistan ve İran devletlerinden oluşuyordu. Dünya kamuoyunda "kızıl düşman" olarak kısa sürede bir alg1 olarak yerleşmeye başlayan Sovyet komünizm tehlikesi karşısında başta Amerika Birleşik Devletleri olmak üzere Batı Avrupa devletleri

\footnotetext{
${ }^{3}$ The Times, Jun 01, 1946, Issue: 50467, p. 5.

${ }^{4}$ The Times, Jun 01, 1946, Issue: 50467, p. 7.

${ }^{5}$ Fahir Armaoğlu, 20. Yüzyıl Siyasi Tarihi 1914-1980,Cilt: I; Türkiye İş Bankas1 Yayınları, Ankara 1991, s. 423.
}

\section{5}

Güvenlik Stratejileri

Cilt: 17

Say1: 37 
6

Güvenlik

Stratejileri

Cilt: 17

Sayı: 37

savaştan hemen sonra hızla harekete geçmişler ve komünizm tehlikesi karşısında birtakım ciddi ve etkin tedbirler almaya başlamışlardır. Bu çerçevede 22 Mart 1947 tarihinde Başkan Truman tarafindan Amerikan Kongresi'nde yapılan konuşma ve sonrasındaki gelişmeler komünizm ile sistematik bir mücadelenin başlangıcını teşkil ederken "Soğuk Savaş" kavramının da uluslararası ortamda tek kabul gören gerçeklik olmasına zemin hazırlamıştır. Artık tüm dünya ve uluslararası ilişkiler bu kavram üzerinden şekillenmek zorundaydı ve gerçekten de yüzyılın neredeyse son dilimine kadar da öyle olmuştur. Başta Truman doktrini ve bu çerçevede ortaya konulan Marshall Yardım Planı gibi öncelikle Batı Avrupa'nın ekonomi bakımından komünizm karşısında sağlamlaştırılması için alınan bazı etkili tedbirler kısa sürede çok daha geniş coğrafyaları da içine alacak biçimde genişletilerek Sovyet komünizmi karşısında önemli adımlar atılmıştır. Komünizm tehlikesi karşısında atılan bu adımlar sadece ekonomik tedbirler ile sınırlı kalmamış ABD'nin başını çektiği bu mücadelede her enstrüman etkin bir şekilde kullanılarak komünizmin tüm dünya milletlerini esir ve köle yapmak üzere ortaya çıktığı algıSı ABD öncülüğünde bütün dünyada hâkim düşünce haline getirilmiştir. ABD öncülügünde başlatılan Sovyet komünizmi ile mücadelenin en etkin araçlarından biri komünizm tehlikesi karşısında oluşturulan uluslararası örgütlerdir. Askerî, siyasi ve ekonomik alanda Soğuk Savaş sürecinde komünizm tehlikesi karşısında önemli uluslararası örgütler kurulmuş ve bu örgütler aracıllı̆̆ıla komünizm karşıtı düşünce oluşturulmaya çalışılmıştır. Bu örgütlerden en önemlisi 1949 yılında kurulan NATO olmuştur. NATO, kurulduğu andan itibaren komünizm karşısında başta askerî olmak üzere en etkin siyasi mücadele aracı haline gelmiştir. Bundan başka 1957'de kurulan Avrupa Ekonomi Topluluğu (AET) da komünizmle mücadelenin ekonomik boyutunu teşkil etmiş güçlü bir uluslararası örgüt halini almıştır. Komünizm karşısında uluslararası örgütlenme yukarıda adı geçen örgütlerle de sınırlı kalmamıştır. Komünizm tehlikesi zaman zaman bazı bölgesel birlikteliklere de zemin hazırlamıştır. $\mathrm{Bu}$ bölgesel oluşumlar özellikle Sovyet komünizminin doğrudan tehdidi altında olan alanlarda öncelikli hale gelmiştir. Soğuk Savaş sürecinde zaman zaman komünizm tehlikesi karşısında ortaya çıkan bu tür 
Soğuk Savaş Sürecinde Komünizme Karşı Türkiye'nin Uluslararası Güvenlik ve Savunma İşbirlikleri Kurma Çabaları: Balkan Paktı ve İttifakı

bölgesel oluşumlardan en önemlisi Balkan Paktı (1953) ile Balkan İttifakı (1954) olmuştur. Balkan Paktı ve İttifakı'nın ortaya çıkışında ise özellikle 1952 tarihinde NATO'ya üye olarak komünizm karşıtı blokta olduğunu resmen ispatlayan Türkiye önemli rol oynamıştır. Çünkü Türkiye stratejik açıdan Akdeniz ve Orta Doğu'da önemli bir coğrafyada bulunuyor ve şimdi komünizm tehlikesi Türkiye'nin bu önemini ve komünizmle mücadelede Türkiye'ye olan ihtiyacı bir kez daha gözler önüne seriyordu. Bu öneminin farkında olan Türkiye hem NATO'ya üyeliğinin yüklemiş olduğu ağır sorumluluk hem de bölgesinin daha güvenli hale gelmesinde üzerine düssen görevi yerine getirebilmek için derhal harekete geçerek Balkanlarda komünizm karşıtı bir oluşumun ortaya çıkmasında önemli bir rol oynamıştır.

\section{Balkan Paktı (28 Şubat 1953)}

Tarih boyunca birçok ulusun yerleştiği Balkan coğrafyası stratejik açıdan Avrupa'nın olduğu kadar başta Türkiye olmak üzere Akdeniz ve Orta Doğu'nun güvenliği açısından önemli bir rol oynamıştır. $\mathrm{Bu}$ stratejik önemi ve sahip olduğu çelişik ve karmaşık demografik yapısından dolayı Balkanlar özellikle 20. Yüzyıl başından beri de büyük güçlerin nüfuz mücadelesi yürüttükleri alanlarından en önemlisi olmuştur. Soğuk Savaşın başlaması ve özellikle Orta ve Doğu Avrupa üzerindeki Sovyet komünist baskısı Balkanları başta Avrupa olmak üzere Türkiye ve etrafı açısından oldukça önemli hale getirmiştir. Soğuk Savaş'ın başlamasıyla birlikte Balkan yarımadası uluslararası ortamın aldığı yeni şekil doğrultusunda iki blok arasında ayrılmıştı. Bu iki blok ise bir yanda komünizmin merkezi Moskova'dan destek alan ve idare edilen bir kısım Balkan devletleri ile ABD'den destek alan Yunanistan ve Türkiye'den oluşuyordu. Balkan yarımadasındaki bu bölünmüşlük, Moskova'dan bağımsız hareket ettiği ve farkı politikalar izlediği gerekçesiyle Tito önderliğindeki Yugoslavya'nın komünizmin en etkin birlikteliklerinden olan Kominform'dan çıkarılmasıyla yeni bir boyut kazanmıştır. ${ }^{6}$ Moskova ile ilişkileri bozulan Yugoslavya

\footnotetext{
${ }^{6}$ Türk Dış Politikası, Cilt: I 1919-1980, Baskın Oran (ed.), İletişim Yayınları, İstanbul,
} 
sadece ekonomik güçlüklerle baş etmekle kalmıyor, bir de ciddi güvenlik endişesi duyuyordu. ABD, bu durumdan yararlanarak Belgrad'a önce

Güvenlik Stratejileri

Cilt: 17

Sayı: 37 ekonomik sonra da askerî yardım göndererek durumu lehine çevirmeye ve Yugoslavya'yı Batı Bloku içine dâhil ederek Batı Avrupa'nın güvenliğini ve Sovyet komünizmini çevrelemeyi hedefliyordu. ABD, 1949 yllinda NATO'yu kurmak ve 1952'de NATO'ya Yunanistan ve Türkiye'yi dâhil etmek suretiyle bu çevreleme politikasında etkin bir adım da atmıştı zaten. Şimdi Yugoslavya'yı da bir şekliyle bu sürecin içinde dâhil ederek çevreleme politikasında önemli bir gelişme sağlamak niyetindeydi. Bunun için de ABD, NATO dişında özellikle Balkanlar ve Orta Doğu'da kurulacak ittifaklar ile SSCB'yi çevreleyecek bununla da kalmayıp, NATO'nun askerî savunma hattını Atlantik'ten İran'a uzatmış olacaktı. Bunun için Yugoslavya'yı ikna etmek bir şekliyle bir birlikteliğe sokmak gerekiyordu. Sosyalist bir lider olan Tito'yu NATO gibi bir birliğe dâhil etmek mümkün olmadığına göre Türkiye ve Yunanistan gibi NATO üyesi bir ülke aracılığıyla ve farklı bir birlik oluşturmak suretiyle ancak bu başarılı olabilirdi. ${ }^{7}$ Nihayet ABD, Türkiye ve Yunanistan'in NATO üyeliklerinden hemen sonra Türkiye, Yugoslavya ve Yunanistan arasında bir Balkan Paktı kurulması bunun için de Ankara, Atina ve Belgrad'ın yakınlaşmasını teşvik etmeye başlamıştır. ${ }^{8}$

ABD'nin Sovyet komünizmini çevreleme politikasında Türk dış politikası da oldukça gönüllüydü. Mayıs 1950 seçimleri ile iktidara gelen Demokrat Parti yeni dış politikada uluslararası yeni şartları dikkate alarak tavrını ABD'nin başını çektiği Batı bloğundan yana koymuştu. Demokrat Parti hükümetleri 1960 yılına kadar bu diş politikadan vazgeçmemişler yükselen güç olan $\mathrm{ABD}$ ile yakın ilişkiler kurmak ve her şekilde bunu korumak ve sürdürmek yönünde çaba göstermişlerdir. ABD ile ilgili olarak "ne kadar uyumlu çalışırsak o kadar dış yardım alırız" beklentisi içindeki Demokrat Parti hükümetleri

2002, s. 588.

${ }^{7}$ Türk Dış Politikası, s. 588.

${ }^{8}$ Olaylarla Türk Dış Politikası, Cilt: I 1919-1973, Haz. Mehmet Gönlübol, Cem Sar, AÜ Siyasal Bilgiler Fak Yayınları, Ankara, 1987, s. 237. 
Soğuk Savaş Sürecinde Komünizme Karşı Türkiye'nin Uluslararası Güvenlik ve Savunma İşbirlikleri Kurma Çabaları: Balkan Paktı ve İttifakı

$\mathrm{ABD}$ ile ilişkileri sürdürmenin koşulunun da neler olduğunu çok iyi kavramışlardı. Bundan dolayı da Kıbrıs, Orta Doğu ve Balkan Paktı konularında ne yapılması gerekiyorsa ona göre hareket etmekten çekinmediler. ${ }^{9}$

ABD etkisinde gelişen Türkiye önderliğinde Balkanlarda komünizm karşısında işbirliği oluşturma çabaları Türkiye açısından ilk tecrübe ve deneyim değildi. Soğuk Savaştan çok daha önce Türkiye, daha iki savaş arası dönemde Balkan ülkeleri ile işbirliği konusunda teşebbüslerde bulunmuş ve 1934 yılında Balkan Antantı (Balkan Paktı) adıyla Bulgaristan'ın revizyonist arzu ve istekleri karşısında bir blok oluşturmayı başarabilmişti. ${ }^{10}$

Sadece ABD'nin komünizm karşısında güçlü bir blok oluşturma ve Sovyet komünizmini çevreleme ve bunun için de en müsait devlet olarak Türkiye'nin Balkanlarda öncü bir rol ile bir birliktelik oluşturma istekleri değil aynı zamanda balkanlardaki bazı gelişmeler ve özellikle Türkiye'nin NATO üyeliğinden sonra Sovyet Rusya ve Bulgaristan tarafından sürekli baskı altına alınmaya çalışılması da Türkiye'yi Balkanlar konusunda endişelendirmiş ve harekete geçmesinde etkili olmuştur. Türkiye'nin NATO'ya girme isteği ve çabalarına sert tepki gösteren Sovyet Rusya bu tepkisini 13 Kasım 1951 tarihli bir nota ile Türkiye'ye bildirmişti. Söz konusu notada Sovyet Rusya, doğrudan kendisine yönelik olarak oluşturulmuş bir teşkilat olan NATO'ya Türkiye'nin dâhil olmasının Sovyetlerle olan ilişkilere büyük zararlara vereceğini ileri sürüyordu. ${ }^{11}$ Sovyet Rusya, ayrıca, Türkiye üzerinde yapmakta olduğu baskı için Bulgaristan'ı da aracı olarak kullanıyordu. Bulgaristan'ın 1950-1951 yıllarında ülkesindeki Türkleri göçe zorlama politikası Türkiye'de endişe uyandırmış ve bu baskıların Sovyet etkisiyle

\footnotetext{
${ }^{9}$ Özcan Gencer, “Ellili Yıllarda Dış Politika”, Türkiye'nin 1950’li Yılları, Mete Kaan Kaynar(ed.), İletişim yayınları, İstanbul, 2015, s. 97.

${ }^{10}$ Türkiye'nin Balkan politikası ve Balkan Antantı için bkz. Hikmet Öksüz, "Türkiye Cumhuriyeti Devleti'nin Balkan Politikası", Türk Dış Politikası: Cumhuriyet Dönemi, 2. Kitap, Mustafa Bıyıklı,(ed.), Gökkubbe Yayınları, İstanbul, 2008

${ }^{11}$ Rifat Uçarol, Siyasi Tarih (1789-1994),Filiz Kitabevi, İstanbul, 1995, s. 731.
}

Güvenlik

Stratejileri

Cilt: 17

Say1: 37 
10

Güvenlik Stratejileri

Cilt: 17

Sayı: 37

gerçekleştiği düşüncesine varılmıştı. Bulgaristan ayrıca, Türkiye'nin NATO'ya dâhil olmasından da pek menün değildi. Bundan dolayı iki ülke arasındaki ilişler karşılıklı şüpheler üzerinde yürütülmeye çalış1lyyordu. $^{12}$

Böyle bir ortamda Türkiye gerek dâhil olduğu Batı Bloku'nun kuvvetli telkinleri gerekse kendi güvenliği için Balkanlarda Sovyet etkisi dışında kalan ve Sovyet baskılarına dayanan bazı Balkan ülkeleri ile sıkı bir işbirliği içine girerek Balkan Paktı için gerekli adımları atmaya başlamıştır. Bunun için de özellikle Yunanistan ve Yugoslavya en uygun ülkeler olarak görülüyordu. Şu bir gerçekti ki, her üç devlet de Türkiye, Yunanistan ve Yugoslavya, her şeyden önce II. Dünya Savaş1 sonrası oluşan yeni uluslararası ortam ve gelişmeler karşısında ciddi ekonomik yardım ihtiyacı içindeydiler. Balkan Paktı'na imza koyan üç devlet de savaşın ağır ekonomik zorlukları altındaydılar ve bu ekonomik zorlukların üstesinden gelebilmek ve kalkınma sürecini başlatabilmek için 1948 yılından beri almaya çalıştıkları ABD yardımlarına şiddetle ihtiyaç duyuyorlardi. NATO'nun savunma stratejisini güçlendirecek bir Balkan Paktı, Batı'dan gelecek askerî ve ekonomik yardımları arttırabilirdi. ${ }^{13}$ Ayrıca Yugoslavya, Trieste sorununda İtalya'ya karşı güçlü bir konumda olmak isteği içindeydi. II. Dünya Savaşı sonrasında imzalanan Paris Barış Antlaşmasıyla Trieste, serbest kent olarak kabul edilmişti. Savaştan sonra müttefiklerle yakın ilişkiler içine giren İtalya'nın Trieste üzerinden Balkanlarda yeniden güçlü hale gelmesi Yugoslavya'yı endişelendiriyordu. ${ }^{14} \mathrm{Bu}$ açıdan Balkanlarda oluşturulacak bir birliktelik Yugoslavya için de oldukça önem arz ediyordu.

Kurulacak Balkan Paktı'nın önemli bir unsurunu teşkil eden Yunanistan ise, kuzey komşularının desteklediği bir iç savaştan yeni çıkmıştı. Bulgaristan ile arası oldukça kötüydü. Bulgaristan'ın komünist Yunan çetelerine yataklık yapması, Makedonya'dan karşılıklı toprak

\footnotetext{
${ }^{12}$ Uçarol, a.g.e., s. 732.

${ }^{13}$ Türk Dış Politikası, Baskın Oran,(ed.), s. 589.

${ }^{14}$ A.e., s. 589.
} 
Soğuk Savaş Sürecinde Komünizme Karşı Türkiye'nin Uluslararası Güvenlik ve Savunma İşbirlikleri Kurma Çabaları: Balkan Paktı ve İttifakı

istekleri, azınlıklar, Bulgaristan'ın Ege denizine çıkmak istemesi gibi nedenler Bulgar Yunan ilişkilerinin bozulmasının temel nedenlerini oluşturuyordu. Sovyetler tarafindan özellikle havadan desteklenecek Arnavutluk da Yunanistan için ayrı bir tehlike oluşturuyordu. Bu durumda Yunanistan, Arnavutluk ve Bulgaristan'a karşı güvenliğini sağlamak için Türkiye ve Yugoslavya ile işbirliği yapmaktan yanayd ${ }^{1}{ }^{15}$

Yukarıdaki anlatılar dikkate alındığında Sovyet komünizmi ve onun uydusu haline gelmiş Balkan devletlerinin politik hesaplarının başta Türkiye olmak üzere Yunanistan ve Yugoslavya tarafindan iyi okunması kaçınılmaz bir gerçeklik olarak ortada duruyordu. $\mathrm{Bu}$ gerçeklik de kısa sürede Türkiye'yi harekete geçirmiş ve Balkan Paktı için geri sayım başlamıştır.

Balkan Paktı'nın kurulması yönündeki çalışmalar 1952 yılının son aylarında hız kazanmıştır. Ocak 1953 'ten itibaren ise Türk dış politikasının en önemli gündemi haline gelmiştir. Balkan Paktı ile ilgili çalışmalar başlangıçta Türkiye öncülüğünde Yunanistan ve Yugoslavya'dan başka İtalya'nın da sürece dâhil edilerek Balkanlarda dörtlü bir savunma ve güvenlik potasının oluşturulması düşünülüyordu. Nihayet 31 Aralık 1952 tarihinde Yunanistan Başbakanı Mareşal Papagos Yunanistan, Türkiye ve Yugoslavya arasında başlatılmış olan görüşmelere İtalya'yı da davet etmiş bu ise Yunanistan da geniş yankı bulmuştu. ${ }^{16}$ Hatta Türk ve Yunan Dışişleri Bakanlarının İtalya'da yapmış oldukları görüşmeler neticesinde özellikle İtalya ve Yugoslavya arasında oluşturulacak dörtlü Balkan savunma paktı önündeki engellerin önemli bir kısmının halledilmiş olması büyük başarı olarak görülmüş ve dörtlü bir paktın kurulması yönündeki umutlar iyiden iyiye artmıştı. Özellikle Türk Dışişleri Bakanı Fuat Köprülü'nün İtalya'daki görüşmeleri ve İtalya ile Yugoslavya arasında mevcut sorunların halli konusunda aldığı mesafeyi Yunan Dışişleri Bakanı Stefanopulos

\footnotetext{
${ }^{15}$ Uçarol, a.g.e., s. 732.

${ }^{16}$ Son Posta, 1 Ocak 1953, s. 3.
}

\section{1}

Güvenlik Stratejileri

Cilt: 17

Say1: 37 


\section{Ceyda TUNA KOCAOĞLU}

12

Güvenlik Stratejileri

Cilt: 17

Say1: 37

dikkatle takip etmiş ve takdirle karşılamıştır. ${ }^{17}$ Özellikle 1952 yılı başından beri Türkiye ile Yunanistan arasında oldukça iyi ve sıkı bir ilişki süreci başlamıştı.

30 Ocak 1952 tarihinde Yunan Dişişleri Bakanı Ankara'ya ziyarette bulunmuş, ardından da 22 Nisan ve 22 Haziran 1952 tarihlerine Türkiye ile Yunanistan arasında imzalanan bazı antlaşmalar ile iki devlet arasındaki mevcut sorunların büyük bir kısmı çözüme kavuşturulmuştu. 26 Nisan 1952'de Adnan Menderes ile Fuat Köprülü Atina'ya bir ziyarette bulunmuş yine aynı yıl içinde Cumhurbaşkanı Celal Bayar Yunanistan'1 ziyaret etmişti. ${ }^{18}$ Bu suretle 1952 yılı Türk Yunan ilişkileri açısından oldukça verilmiş geçmiş belki de oluşturulacak Balkan Paktı için ciddi bir zemin hazırlanmıştı. Dolayısıyla Balkan Paktı için öncelikle ikna edilmesi gereken devlet Yugoslavya'ydı.

Yunanistan böyle bir birliktelik için oldukça hazırdı. Ocak 1953 ortalarında bir taraftan Türkiye ile Yugoslavya arasında görüşmeler yoğun bir şekilde devam ediyordu. Türkiye'nin bir süredir, özellikle NATO'ya üyeliği sonrasında, takip ettiği Balkan politikası Batılı devletlerin de dikkatinden kaçmamıştır. 10 Ocak 1953 tarihinde bir Batı Alman ajansının Berlin basınında çıkan haberinde Türkiye'nin özellikle Balkanlar ve Akdeniz'deki çabaları şu cümlelerle anlatılmıştır: "Türkiye, Akdeniz'de sulhün ve mücavir devletlerle sikl dostluk münasebetlerinin devamını istediğinden gerek Balkanlarda ve gerekse Doğu Akdeniz'de böyle bir hava yaratmağa ve bunu idameye çalışmaktadır. Türkiye'nin bu anlayışına ve görüşüne Yunanistan ve Yugoslavya şimdiden iltihak etmiş bulunuyorlar. Bu anlayışın tamamlanması ve kuvvetlenmesi için İtalya'nın da ayn davaya inanması ve katılması lazımdır. Bugün bunun tahakkukuna mani olan yegâne mesele Trieste şehir ve limanlarının gelecekteki mukadderatıdır. Italya, Yugoslavya ile işbirliğine ancak bu meselenin hallinden sonra yanaşacağını müteaddit vesilelerle ihsas etmiştir. Ittalya başvekili

\footnotetext{
${ }^{17}$ Son Posta, 3 Ocak 1953, s. 7.

${ }^{18}$ Son Posta, 3 Ocak 1953, s. 7.
} 
Soğuk Savaş Sürecinde Komünizme Karşı Türkiye'nin Uluslararası Güvenlik ve Savunma İşbirlikleri Kurma Çabaları: Balkan Paktı ve İttifakı

Atina'yl ziyaret ettikten sonra ileride muhtemel olarak Ankara'yı da ziyaret edecektir. Isşte bu esnada Türkiye'nin Yunanistan'la müştereken Trieste meselesine bir hal çaresi ileri sürmesi beklenebilir. Türkiye son zamanlarda takip ettiği realist ve dürüst politikastyla güvenilir, itibarlı bir devlet olarak ortaya çıkmıştır. Bu bakımdan bugün siyasi, iktisadi ve askerî münasebetlerini genişlettiği Yugoslavya'nın üçüzlü davasının milletlerarası görüş ve anlayış içinde Yunanistan, Yugoslavya ve İtalya ile müsstereken müzakere edilerek halli ve müsbet neticeye bağlanmasını ve bu suretle komünizme karşı Balkan blokunun dimdik ayakta durmasını isteyeceği tabii görülebilir". ${ }^{19}$

Türkiye'nin bütün çabalarına rağmen özellikle İtalya'nın bloğa dâhil olması süreç ilerledikçe güç bir konu halini almaya başlamıştır. 11 Ocak 1953'te Belgrat radyosunda yayınlanan bir haberde İtalya'nın üçlü Balkan Bloku'nu baltalamaya çalıştığı ileri sürülmüştür. Belgrat radyosundaki haberde İtalya'nın Yunanistan'daki görüşmelerine değinilerek, İtalya'nın bu görüşmelerde asıl hedefinin Balkan savunması için Türkiye, Yugoslavya ve Yunanistan arasında kurulması düşünülen Balkan Paktı'nın başına geçmek olduğu ve bunun için de üç devletin arasını bozmak olduğu ifade edilmiştir. Bununla birlikte haberde İtalya'nın gerçekte bu amacına ulaşamayacağı üç devletin İtalya olmadan da bir araya gelerek bir birliktelik oluşturacağı da vurgulanmıştır. ${ }^{20}$ Yugoslavya, İtalya ile ilgili endişelerinde haklı görünüyordu. Çünkü Atina'daki görüşmelerini tamamladıktan sonra Roma'ya dönen İtalya Dışişleri Bakanı De Gasperi, Roma'da yaptığı açıklamada Balkan Paktının ön şartı olarak Trieste sorununu görüyordu. ${ }^{21}$

$\mathrm{Bu}$ arada Türkiye Dışişleri Bakanı Fuat Köprülü’nün 20 Ocak 1953 tarihinde Belgrat'ta ve hemen sonrasinda yani 26 Ocak 1953 tarihinde Atina'da yapacağı görüssmeler öncesinde konuyu yakından takip eden Türk basını Yugoslavya'nın Türkiye ile askerî bir ittifak

\footnotetext{
${ }^{19}$ Son Posta, 11 Ocak 1953, s. 7.

${ }^{20}$ Son Posta, 12 Ocak 1953, s. 7.

${ }^{21}$ Son Posta, 13 Ocak 1953, s. 1.
}

\section{3}

Güvenlik Stratejileri

Cilt: 17

Say1: 37 


\section{Ceyda TUNA KOCAOĞLU}

14

Güvenlik Stratejileri

Cilt: 17

Say1: 37

yapmak konusunda oldukça istekli ve buna da çok önem verdiği yönünde haberlere yer veriyordu. ${ }^{22}$ Türk basınında ayrıca, Dışişleri Bakanı Fuat Köprülü'nün 20 Ocak'ta gerçekleşecek ziyaretin detaylarına geniş yer veriliyor ve kurulacak Balkan Paktının özellikle askerî bir savunma tedbiri olacağından bahsediliyordu. ${ }^{23}$ Fuat Köprülü seyahatinden önce basına yaptığı açıklamada; Yugoslavya ve sonrasında yapacağı Yunanistan ziyaretleri hakkında şunları ifade etmiştir:

"Yugoslavya'ya yapacağım ziyaret, iki devlet arasinda her sahada gelişmekte olan ve yalnı iki taraf için değil mensup olduğumuz hür devletler camiası için de çok hayırlı anlayıs ve dostluğun neticesi ve tezahürüdür. İki memleketi alakadar eden meseleler hakkında Yugoslav devlet adamları ile çok geniş fikir teatisinde bulunmak imkânının elde etmiş olacağım. Realist, cesur ve dürüst Yugoslav milletinin değerli devlet reisi ve devlet adamlartyla doğrudan doğruya görüsmek ve esasl fikir teatisinde bulunmak benim için büyük bir zevk olacaktır. Müttefikimiz Yunanistan ile aramızdaki münasebetlerin ne kadar ileri ve itimatkâr olduğunu biliyorsunuz. Onun için bu hususta ayrıca bir şey söylemeye lüzum görmüyorum. Parlak bir ekseriyetle iktidar mevkiine gelen Yunan hükümetinin klymetli ricali ile her zaman yaptı̆̆ımız gibi genis fikir müdavelelerinde bulunabilecek olmaktan çok bahtiyarım."24

Nihayet Türk Dışişleri Bakanı Fuat Köprülü 20 Ocak 1953 tarihinde Belgrat'a varmış ve 5 gün sürecek temaslarına başlamıştır. Köprülü’nün bu ziyareti Balkan Paktının kurulmasında önemli rol oynamıştır. En az Türk basını kadar Yugoslav basını da konuya yoğun ilgi göstermiş ve Köprülü'nün ziyaretine sütunlarında geniş yer vermiştir. $^{25}$

\footnotetext{
${ }^{22}$ Son Posta, 16 Ocak 1953, s. 7.

${ }^{23}$ Son Posta, 17 Ocak 1953, s. 7.

${ }^{24}$ Son Posta, 19 Ocak 1953, s. 7.

${ }^{25}$ Son Posta, 21 Ocak 1953, s. 7.
} 
Soğuk Savaş Sürecinde Komünizme Karşı Türkiye'nin Uluslararası Güvenlik ve Savunma İşbirlikleri Kurma Çabaları: Balkan Paktı ve İttifakı

Köprülü ilk görüşmesini Yugoslav Dışişleri Bakanı Papaviç ile gerçekleştirmiştir. Yugoslav bakan söz konusu görüşmeler ile ilgili olarak, gerçek barış dostlarının ortaya çıkacak bu eseri gönülden destekleyecekleri değerlendirmesinde bulunmuş ve mevcut şartlar ve her iki ülkenin güvenlik ve menfaatlerinin Balkanlarda kurulacak bir savunma birliğinde olduğunu ileri sürmüştür. Papaviç'in bu değerlendirmelerine karşılık olarak Köprülü de görüşmeler ile ilgili olarak yaptığı açıklamasında şu değerlendirmelere yer vermiştir: "Münasebetlerimizi ve işbirliğimizi her sahada kuvvetlendirmek yalnı kendi memleketlerimize ve müşterek menfaatlerimize karşı bir vazife değil, aynı zamanda Birleşmiş Milletler camiasına karşı bir borçtur...,26 Köprülü bu değerlendirmesiyle kurulacak Balkan Paktı'nın arka planını da açıkça dile getirmiş oluyordu. Gerçekten de bu ziyaret Balkan Paktı'nın da temelini oluşturmuştur. Köprülü bu ziyareti esnasında Yugoslav Dışş̧leri bakanından başka Tito ile de etraflı bir görüşme gerçekleştirmiştir.

22 Ocak akşamı Brioni adasındaki köşkünde Fuat Köprülü onuruna verdiği yemekte bir konuşma yapan Tito, gelişmeler hakkında önemli değerlendirmelerde bulunmuş ve Balkan Paktı'nın önemine dikkat çekmiştir. Tito konuşmasında şu değerlendirmeleri yapmıştır: "Türkiye, Yunanistan ve Yugoslavya'yl ilgilendiren birbirine benzer birçok meseleler vardır. Bunlar, aynı düşman tarafindan tehdit edilen bağımsızlı̆̆ımız, toprak bütünlügü̈müz ve Balkan yarımadasının barışı bakımından menfaatlerimizi teşkil eder. ${ }^{, 27}$ Tito konuşmasında ayrıca Türk Dışişleri Bakanının Yugoslavya'ya gelişinin işbirliğini geliştirmek yönünde büyük önem taşıdığına da vurgu yaparak şunları söylemiştir:

" $\ddot{U} c ̧$ ülkenin Balkan yarımadasında giriştikleri bu işbirliğinin barlş yanlisı bütün hükümetler tarafindan tasvip edileceğini ve Balkanlarda barış ve istikrarın sağlanmasının dünya barışını da katkı să̆layacă̆ını dile getirmiş̧tir. İşbirliğimiz, dürüst

\footnotetext{
${ }^{26}$ Son Posta, 22 Ocak 1953, s. 7.

${ }^{27}$ Son Posta, 23 Ocak 1953, s. 7.
} 


\section{Ceyda TUNA KOCAOĞLU}

16

Güvenlik Stratejileri

Cilt: 17

Sayı: 37

niyetlileri hiçbir zaman tehdit etmemektedir. Bu, barış̧̧ı, yapıcı ve sadece izim için değil aynı zamanda bütün barlşsever milletler için faydalı bir işbirliğidir. Bu işbirliğinin, müşsterek menfaatlerimizin müdafaası için en müessir şsekilde devam edeceğine kaniim. Resmî mükellefiyetler münasebetlerimizin istikbalde normal bir şekilde gelişmesine mani teşkil etmez. Bizce bu mükellefiyetler yapılması lazım gelen şeyi teyid etmektedir. ... Biz şimdiye kadar resmî antlaşmaların milletlerimizin hayati menfaatlerinden doğan hakiki bir işbirliği kadar mühim olmadıklarını her zaman beyan etmiş bulunuyoruz. Hayati menfaatlerimizi ve bunların maruz bulunduğu tehlikeleri müdrik olduğumuz içindir ki, işbirliğimiz hakiki ihtiyaçlara uygun olarak bugünkü milletlerarası durumla hemahenk ve memleketlerimizin kendilerine has telakkilerine muvafik bir şekilde gelişmektedir." 28

Tito 23 Ocak sabahı da Fuat Köprülü ile görüşmüş ve bu görüşmeler sonunda Türkiye ile Yugoslavya arasında Balkanların savunması ve iki devlet arasındaki ilișkilerin her alanda geliștirilmesi konularında tam bir görüş birliğine varılmıştır. ${ }^{29}$ Görüşmeler ile ilgili olarak ayrıca ortak bir tebliğ de yayınlanmış ve söz konusu tebliğde iki ülkenin mevcut işbirliklerini genişletmesi, özellikle ortak güvenliklerini ilgilendiren günün sorunları ve aynı zamanda Balkanlarda barış korunması ve sürdürülebilmesi için önem arz eden diğer sorunlar hakkında etraflıca fikir alışverişinde bulunulduğu bildirildikten başka, iki devletin barış ve güvenliğin korunması hususunda gelecekteki işbirliklerine tam bir şekil ve yön verilmesinin bir an önce lüzumlu olduğu ve bunun için iki

${ }^{28}$ Son Posta, 23 Ocak 1953, s. 7.

2923 Ocakta yapılan görüşmelere Fuat Köprülü'den başka, Türkiye'nin Belgrat Büyükelçisi Agah Aksel, Türkiye Dışişleri Vekaleti Müsteşarı Nuri Birgi, Genel Müdür Adnan Kuran, Yugoslav Fedaral İcra Başkan Yardımcısı Edguard Kardelj, Yugoslav Dışişleri Bakanı Koça Papaviç, Yugoslavya'nın Ankara Büyükelçisi Lubomir Radovaniviç, Yugoslav Dışişleri Vekaleti büyükelçilerinden Jessip Djerdja, Protokol Şefi Dr. Slovan Smodlaka katılmışlardır. Bkz: Son Posta, 24 Ocak 1953, s. 7. 
Soğuk Savaş Sürecinde Komünizme Karşı Türkiye'nin Uluslararası Güvenlik ve Savunma İşbirlikleri Kurma Çabaları: Balkan Paktı ve İttifakı

ülkenin tam bir görüş birliği içinde olduğu ve görüşmelerin tam bir dostluk ve karş1lıklı güven içinde gerçekleştirildiği ifade edilmiştir. ${ }^{30}$ Görüşmeler sonrasında Fuat Köprülü Atina'ya hareketinden önce Belgrat'ta düzenlediği bir konferansta Türkiye, Yunanistan ve Yugoslavya arasında bir Balkan Paktı'nın kurulması ümitlerinin çok kuvvetli olduğunu söylemiştir. ${ }^{31}$ Türkiye Yugoslavya görüşmeleri Yugoslavya basınında geniş yankı bulmuş ve görüşmeler Yugoslavya basını tarafından olumlu karşılanmış övgü dolu yazılar yayınlanmıştır. ${ }^{32}$

Türkiye Yugoslavya görüşmelerinin ardından Türk Dışişleri Bakanı Fuat Köprülü 26 Ocak'ta Atina'ya geçmiştir. Fuat Köprülü’nün Atina'daki görüşmelerinde Atlantik Paktı Teşkilatı'nın Güney Avrupa Başkumandanı Amiral Robert Carney ve Akdeniz Bölgesi Başkomutanı İngiliz Amirali Lord Mountbatten ile yapacağı görüşmeler oldukça önem arz ediyordu. Bu görüşmelerde NATO çerçevesinde Balkanların ortak güvenliği ve Akdeniz'in savunmasına dair sorunlar etraflıca ele alınacaktı. ${ }^{33}$ Nihayet 27 Ocak’ta Fuat Köprülü önce Yunan Başvekili Papagos ve Dışişleri Bakanı Stefanopulos ile resmî görüşmeleri başlatmıştır. Bu görüşmelerde Köprülü, öncelikle Yugoslavya ve özellikle Tito ile ilgili görüşmeleri hakkında Yunan tarafını bilgilendirmiştir. ${ }^{34}$ Görüşmeler 28 Ocak'ta tamamlanmıştır. Atina görüşmeleri neticesinde Türkiye Yugoslavya ve Yunanistan arasında Mart ayı başlarında Ankara'da bir paktın imzalanması kesin bir şekilde kararlaştırılmıştır. ${ }^{35}$ Fuat Köprülü'nün Atina'daki müzakereleri hakkında Yunan hükümeti bir tebliğ yayınlamıştır. ${ }^{36}$ Köprülü Atina'dan ayrılmadan önce yaptığı

\footnotetext{
${ }^{30}$ Son Posta, 25 Ocak 1953, s. 7.

${ }^{31}$ Son Posta, 25 Ocak 1953, s. 7.

${ }^{32}$ Son Posta, 26 Ocak 1953, s. 7.

${ }^{33}$ Son Posta, 27 Ocak 1953, s. 6.

${ }^{34}$ Son Posta, 28 Ocak 1953, s. 6.

${ }^{35}$ Son Posta, 29 Ocak 1953, s. 6.

${ }^{36}$ Söz konusu tebliğde Köprülü'nün Atina temasları hakkında şunlar söylenmiştir: "Türkiye Cumhuriyeti Dışişleri Vekili Ekselans Profesör Fuad Köprülü Yunan memleketinin davetine icabetle 26 Ocak 1953 de Atina'ya varmıştır. Ekselans Fuad Köprülü bu vesile ile başvekil ekselans Mareşal Papagos ve Hariciye nazırı ekselans
} 


\section{Ceyda TUNA KOCAOĞLU}

18

Güvenlik

Stratejileri

Cilt: 17

Sayı: 37

açıklamasında Yugoslavya'nın NATO'ya bağlanması gereğinden bahsetmiş ve Fransız basınında geniş yer verdiği şu değerlendirmede bulunmuştur:

“Balkan Antant NATO'dan ayrlamaz. Rusya'nin veya peyklerinden birinin Balkan memleketlerinden herhangi birine yapacă̆ taarruz ister istemez bütün NATO memleketlerini harekete geçirecektir. Binaenlaeyh Balkan Paktı ile NATO arasında sık bir teşriki mesai bizzat mantık lüzumlu kılmaktadır. Fakat, bir taraftan İtalya'nın endişelerini bertaraf etmek diğer taraftan ise Tito siyasetinin yeni istikameti hakkında Yugoslav Komünist Partisini ikna zarureti, kati neticeye ulaşmak için sabırl ve realist olmayl amirdir., ${ }^{, 37}$

Köprülü bu açıklamalarıyla uluslararası zorunluluk ve gerçekleri açık bir dille ifade etmiştir. Türkiye'nin çabalarını yakından takip eden ve Balkanlarda Türkiye Yunanistan ve Yugoslavya arasinda kuvvetlenen işbirliğinden büyük bir memnuniyet duyan Amerika Birleşik Devletleri Balkan Paktı'nın bir an önce kurulmasına büyük önem veriyordu. Bu arada şubat ayı başlarında Türkiye ile Yugoslavya arasında ticaret antlaşması yapmak üzere Yugoslavya'ya gönderilmiş olan Türk Parlamento Heyeti Başkanı Hulusi Köymen, Tito'yu Türkiye'ye davet etmiştir. $^{38} \mathrm{Bu}$ görüşmelerde Tito, Balkan Paktı'nın daha fazla

Stefanopulos ile iki memleket arasındaki münasebetlerin mümeyyiz evsafi olan ananevi samimi dostluk ve derin anlayış zihniyetiyle meşbu görüşmelerde bulunmuştur. Tam bir görüş birliğini bir defa daha tecelli ettiren bu görüşmeler siyasetlerini ahenkleştirmeye devama karar vermiş bulunan iki hükümeti alakadar eden bilcümle beynelmilel meseleler üzerinde cereyan etmistir. Hassaten Fuad Köprülü Yunan Hükümetini, Yugoslav devlet adamlariyla Belgrad'da son günlerde yaptı̆̆ görüşmelerden haberdar etmiştir. Yugoslavya Yunanistan ve Türkiye arasinda şimdiden kurulmuş bulunan itimad ve dostluk kendi coğrafi mıntıkalarında bir istikrar unsuru teşkil etmekte olduğundan emniyet ve sulhun idamesi müşterek gayesi bakımından Yugoslavya ile olan münasebetlerinin inkişafi hususunda iki hükümet arasında tam mutabakat mevcut olduğu memnuniyetle müşahede olunmuştur.” Bkz: Son Posta, 1 Şubat 1953, s. 6.

${ }^{37}$ Son Posta, 1 Şubat 1953, s. 6.

${ }^{38}$ Son Posta, 4 Şubat 1953, s. 6. 
Soğuk Savaş Sürecinde Komünizme Karşı Türkiye'nin Uluslararası Güvenlik ve Savunma İşbirlikleri Kurma Çabaları: Balkan Paktı ve İttifakı

geciktirilmeden bir an önce imzalanması gereğinin altını çizmiştir. ${ }^{39}$ 7 Şubat 1953'te Yunan Dişişleri Vekili Stefanopulos, Belgrat'ta yaptığ 1 basın toplantısında Balkan Paktı'na isteyen her memleketin girebileceğinden bahsetmiş ve Şubat ayı içinde paktın Türkiye Yunanistan ve Yugoslavya arasında imzalanacağını duyurmuştur. ${ }^{40}$ Nihayet Şubat ayı ortalarında Ankara'da askerî, Atina'da siyasi müzakerelere başlanması konusunda görüş birliğine varılmıştır. $\mathrm{Bu}$ arada Bulgaristan'ın da Rusya'nın etkisinden kurtulup Balkan Paktı'na dâhil olabileceği ihtimali de özellikle Yugoslav basınında dikkat çeken haberler arasında olmaya başlamıştır. Yugoslav basınında yer alan haberlere göre, bir süredir özellikle Sovyetlerin uzun zamandır izledikleri Ruslaştırma politikasından memnuniyetsizliğin Bulgaristan'da baş gösterdiği bundan dolayı da Bulgar yönetiminin bir an önce Rus baskısından kurtulmayı arzu ettikleri dikkat çeken bir gelişme olarak görülüyor ve uzun zamandır ekonomik zorluklar içindeki Bulgaristan'ın Yugoslavya yanında yer alabileceği değerlendirmesi yapılıyordu. ${ }^{41}$ Balkan Paktı ile ilgili görüşmeler 16 Şubat'ta Ankara'da başlamıştır. Görüşmeler başlamazdan hemen evvel İtalya, kendisinin askerî desteği olmaksızın kurulacak bir paktın hiçbir öneminin olmayacağı yönünde açıklamalarda bulunmuştur. ${ }^{42} 22$ Şubat'ta askerî müzakereler tamamlanmış ve askerî heyetler ülkelerine dönmüşlerdir. Görüşmeler oldukça samimi bir hava içinde geçmiş ve Ankara'da üç devletin bir araya gelerek Balkan Paktı'nı imzalamaları karar altına alınmıştır. Balkan Paktı ilk olarak "Türkiye Cumhuriyeti, Yunanistan Krallığ 1 ve Yugoslavya Federatif Halk Cumhuriyeti Arasında Dostluk ve İşbirliği Antlaşması" resmî adıyla 25 Ocak 1953 tarihinde Atina'da parafe edildikten sonra 28 Şubat 1953'te Ankara'da üç devlet tarafindan imzalanmıştır. ${ }^{43}$ Giriş ve 10 maddeden oluşan Pakt üç devletin dışişleri

\footnotetext{
${ }^{39}$ Son Posta, 7 Şubat 1953, s. 6.

${ }^{40}$ Son Posta, 8 Şubat 1953, s. 6.

${ }^{41}$ Son Posta, 15 Şubat 1953, s.7.

${ }^{42}$ Son Posta, 16 Şubat 1953, s.7.

${ }^{43}$ Türk Dış Politikası, Baskın Oran,(ed.), s. 589.
}

\section{9}

Güvenlik Stratejileri

Cilt: 17

Say1: 37 
20

Güvenlik Stratejileri

Cilt: 17

Sayı: 37

bakanları tarafından resmî bir törenle imza edilmiştir. Antlaşmanın giriş kısmında taraflar, Birleşmiş Milletler Antlaşması'nda belirlenen esaslar ışığında bütün milletler ile barış içinde yaşamak ve uluslararası barışın sürdürmek amacıyla aralarındaki mevcut dostane ilişkileri güçlendirmek ve milletlerin bağımsızlığını ve toprak bütünlüğünün dışarıdan gelecek her türlü kuvvete karşı savunmak ve bunun için bütün güçlerini birleştirmek niyetleriyle bu antlaşmayı Birleşmiş Milletlerin 51. Maddesi gereği olarak imzaladıklarını ifade ediyorlardı. ${ }^{44}$ Antlaşmanın maddeleri şunlarda ibarettir: ${ }^{45}$

1. Taraflar aralarında sürekli biçimde işbirliği yapılmasını sağlamak amacıyla ortak çıkarlarını ilgilendiren bütün sorunlar üzerinde görüş alışverişinde bulunacaklardır. İmzacı devletlerin Dışişleri bakanları uluslararası siyasi gelişmeleri tetkik etmek ve bu antlaşmanın amacına uygun olarak gereken kararları almak üzere düzenli bir şekilde senede bir defa ve gerektiği takdirde daha sık olarak konferanslar düzenleyeceklerdir.

2. Taraflar kendi bölgelerinde barış ve güvenliğin korunması için ortak çabalarına devam etmek ve kendilerine karşı herhangi bir kışkırtma olmadığ halde gerçekleşecek saldırı halinde ortak savunma tedbirleri dâhil olmak üzere güvenlikleri ile ilgili sorunları birlikte tetkike devam etmek kararındadırlar.

3. Tarafların Genel Kurmay Başkanlıkları uyumlu kararların alınabilmesi için aralarında mutabık kalarak tespit edecekleri savunma meselelerine dair tavsiyeleri hükümetlerine bildirmek üzere işbirliği yapmayı sürdüreceklerdir.

4. Taraflar, ekonomik, teknik ve kültürel alanlardaki işbirliğini geliştirecekler; gerektiğinde ekonomik teknik ve kültürel meselelerin halli için antlaşmalar imzalayacaklar ve gerekli teşkilatları kuracaklardır.

\footnotetext{
${ }^{44}$ Son Posta, 1 Mart 1953, s. 7.
}

${ }^{45}$ Son Posta, 1 Mart 1953, s. 7. 
Soğuk Savaş Sürecinde Komünizme Karşı Türkiye'nin Uluslararası Güvenlik ve Savunma İşbirlikleri Kurma Çabaları: Balkan Paktı ve İttifakı

5. Taraflar aralarında çıkabilecek her anlaşmazlığı Birleşmiş Milletler Antlaşmasında tespit edilmiş olan barış̧̧ yollarla ve anlayış ve dostluk ruhu içinde halletmeyi ve birbirlerinin iç işlerine herhangi bir şekilde karışmamayı taahhüt ederler.

6. Taraflar içlerinden birinin aleyhinde veya menfaatlerine zarar getirecek ittifaklara dâhil olmak veya bu türden bir hareket içinde bulunmaktan kaçınacaklardır.

7. Taraflardan her biri kendisi ile üçüncü bir devlet veya diğer devletler arasında geçerli olan uluslararası taahhütlerin hiçbirinin işbu antlaşma hükümlerine aykırı olmadığını beyan eder, diğer taraftan ileride işbu antlaşmaya muhalif olabilecek herhangi bir uluslararası taahhüde girmeyeceğini de kabul etmektedir.

8. İşbu Antlaşma, Türkiye ve Yunanistan'ın 4 Nisan 1949 tarihli Kuzey Atlantik Paktı'ndan kaynaklanan hak ve sorumluluklarına her ne şekilde olursa olsun bir etki etmez ve edecek şekilde yorumlanamaz.

9. Antlaşmanın yürürlüğe girişini takiben antlaşmanın gayelerinin tahakkuku için iştirakleri faydalı görülecek her devlet, antlaşmaya imza koyan üç devletle aynı şartlar altında ve aynı haklara sahip olmak üzere antlaşmaya dâhil olabileceklerdir.

10. Fransızca metni muteber olacak bu antlaşma tarafların her biri tarafindan tasdik edilecek ve tasdiknameler Yugoslavya Federatif Halk Cumhuriyeti Dışişleri Vekâletine tevdi olunacak ve en son tasdiknamenin tevdi edildiği tarihte yürürlüğe girecektir.

Yugoslavya daha Balkan Paktı'nın imzalandığ 1 andan itibaren 4. maddeye özel önem vermiş, askerlik ve güvenlik konuları dışında da üç ülkenin işbirliği yapması üzerinde durmuştur. Bunun için bir örgütlenmeye duyulan gereksinim 7 Kasım 1953 tarihinde Belgrat da imzalanan ek bir anlaşma ile giderilmiş ve daimi sekreterlik kurulmuştur. ${ }^{46}$

\footnotetext{
${ }^{46}$ Türk Dış Politikası Baskın Oran,(ed.), s. 590.
}

\section{1}

Güvenlik Stratejileri

Cilt: 17

Say1: 37 


\section{Ceyda TUNA KOCAOĞLU}

22

Güvenlik

Stratejileri

Cilt: 17

Sayı: 37

Balkan Paktı'nın imza töreni sonrasında ilgili devletlerin dışişleri bakanları antlaşma ile ilgili birer konuşma yapmışlardır. ${ }^{47}$ Balkan Paktı başta ABD olmak üzere Batılı devletler tarafından oldukça olumlu karşılanmıştır. Antlaşma, taraf devletlerin kamuoylarında da olumlu karşılanmıştır. Yunan Dışişleri Bakanı Stefanopulos antlaşmanın barış ve hürriyet taraftarı üç milletin derin hislerinin somut bir hali olduğunu söyleyerek, Antlaşmada hiçbir gizli hükmün bulunmadı̆̆ını "Gizlilik şüpheli taarruz ve istila planları hazırlayanların başvurdukları bir usuldür. Gizli oturumlarl sadece kominform yapar ve suikastçı fikirlerini herkesten saklamak lüzumunu hisseder. Antlaşmamızda hiçbir tecavüz fikri bulunmadığ için bu antlaşma herkese açıtıtır ve iştirak etmek isteyen sulh ve hürriyete inanmış her devleti kabule

${ }^{47}$ Balkan Paktı imza töreninde Fuat Köprülü şu konuşmayı yapmıştır: "Üç memleket arasinda dostluk ve işbirliği antlaşmasinin imzalandı̆̆ bu mühim ve tarihi anda bu vesikanin etrafll tahliline girişmek lüzumunu hissetmiyorum. Zira bütün meseleleri tam aydınlıkla halletmek azminde sadık kalan üç hükümet bizi burada toplamağa sevk eden mesut neticenin muhtelif safhalarına ait çalıșmalar etrafinda dünya efkarı umumiyesini itina ile haberdar etmiş bulunmaktadır. Ben yalnız, bu sulh itilaf vasitasinin derin manasın ifade ile iktifa edeceğim. Bu muahede, Birleşmiş Milletler anayasası prensiplerine

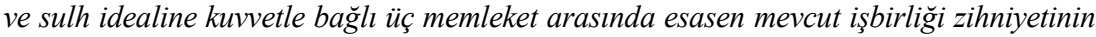
ve samimi dostluğun takdimi olduğu kadar müşterek tehlike muvacehesinde tam bir şuur ile istiklallerini müdafaaya kararlı olan milletlerimizin realist görüşünün de semeresidir. $B u$ itibarla jeopolitik realitelerle bütün sulhperver ve hür memleketlerin müssterek menfaat ve ideallerine tetabuk etmekte bulunan bu muahede sağlam ve zihayat bir vesika olmağa namzettir. Zihayat tabiri üzerinde ısrar etmek istiyorum. Çünkü şimdi hukuki mesnedini bulan işbirliğimizin ifadesini teşkil eyleyen ve iltihakl arzu eden iyi niyetli her memleketin iştirakine açık tutulan bu muahede, zaruretler ve şartların icabettirdiği en iyi tarzda inkişaf eyleyecek ve etmek mecburiyetinde bulunacaktır. Bu dostluk ve işbirliğine yapıcı muayyen istikametti verirken hür dünyaya da realist ve sulhçu inkişaf manzaralartyla zenginleșen yeni bir barlş ve itimad mesnedi getirmiş bulunuyoruz. Türkiye Belgrad'da tasavvur olunan Atina'da tanzim edilen bu işbirliği ve güvenlik vesikasının imzalanıs yeri olmasindan dolayı guru duymaktadır. Bu merasimde Ekselans Yunanistan ve Yugoslavya Dışişleri vekillerinin büyük ve derin bir mana taşıyan huzurlarından kendimizi ne kadar mesut ve müftehir addetmekte olduğumuzu ifadeye müsaadenizi rica ederim. Burada hazır bulunmakla bizlere şeref veren iki dost Dışişleri Vekilini maiyetlerinde bulunduklar muhterem devlet şefleri derecesinde bu vesikanın hazırlanmasında en mühim amil olmuşlardır”. Bkz. Son Posta, 1 Mart 1953, s. 7. 
Soğuk Savaş Sürecinde Komünizme Karşı Türkiye'nin Uluslararası Güvenlik ve Savunma İşbirlikleri Kurma Çabaları: Balkan Paktı ve İttifakı

hazırız" sözleriyle anlatmıştır. ${ }^{48}$ Yunan Başvekil Alexeandre Papagos da Yunan Parlamentosunda yaptığ 1 konuşmasında antlaşma ile ilgili olarak şu değerlendirmeyi yapmıştır:

"Yunanistan'ın, Türkiye ve Yugoslavya ile imzalamış bulunduğu dostluk ve işbirliği andlaşması, bu üç memleket arasındaki münasebetlerde tarihi bir merhale teşkil edecektir ve dolaysıyla 3 memleket arasindaki dostluk münasebetleri daha sikılaşacak, teknik, kültürel ve ekonomik işbirliği daha iyi esaslar üzerine düzenlenecektir. Bilhassa askerî sahada tedadüfi gayretleri koordine edilecektir. Andlaşmada derpiş edildiği veçhile ü̧̧ memleket genelkurmaylarının müşterek savunma bahislerinde hükümetlerine tavsiyelerde bulunmak üzere işbirliği yapmaları Balkan bölgesinde savunma sistemini daha müessir surette düzenleyecektir. Müssterek müdafaanın teşkilatlanması halkın ve bilhassa bu hudut bölgelerinde oturanların himayesini sağlayacak ve bu halka bu suretle emniyet duygusu gelecektir." 49

Balkan Paktı ile ilgili antlaşma Amerika Birleşik Devletleri tarafindan da olumlu karşılanmıştır. Amerika Dışişleri Vekili J. Foster Dulles ile Eden, Türkiye, Yunanistan ve Yugoslavya arasında karşl1ıklı güvenlik antlaşmasını tamamen kabul ettiklerini söylemişler ve İtalya ve Yugoslavya arasında karşılıklı güvenliğin sağlanması konusunda Trieste sorununu çözümünün şart olduğunu da açıkça dile getirmişlerdir. ${ }^{50}$

Bununla birlikte Balkan Paktı Sovyet Rusya'da ciddi endişeye neden olmuştur. Sadece Sovyet Rusya değil uydusu ülkeler de Balkan Paktına sert tavır göstermişlerdir. Moskova radyosu ile Budapeşte, Bükreş, Prag ve Sofya radyoları Ankara'da imzalanan Balkan antlaşması aleyhine yoğun bir propaganda kampanyası başlatmışlardır. $\mathrm{Bu}$ propaganda kampanyas1 Moskova'dan gelen haber metinleri üzerinden gerçekleştirilmiştir. Moskova ve onun güdümündeki ülke radyoları

\footnotetext{
48 Son Posta, 8 Mart 1953, s. 7.

${ }^{49}$ Son Posta, 8 Mart 1953, s. 7.

${ }^{50}$ Son Posta, 8 Mart 1953, s. 7.
}

\section{3}

Güvenlik Stratejileri

Cilt: 17

Say1: 37 
Güvenlik Stratejileri

Cilt: 17

Sayı: 37

Balkan antlaşmasının iddia edildiği gibi barışı korumak için değil aksine komşuları tehdit etmek için hazırlanan bir taarruz paktı olduğunu ileri sürmüşlerdir. ${ }^{51}$ Balkan Paktı Bulgaristan tarafından da yakından takip edilmiştir. Türk Yugoslav işbirliğinin Bulgaristan'daki akisleri hakkında fikirlerini soran Yougopress ajansına Bulgar Mültecileri Birliği Başkanı M. Ivan Monov şunları söylemiştir: "Muhtemel bir taarruza karşı memleketlerinin selametini korumak maksadiyla Türk, Yunan ve Yugoslav hükümetleri tarafindan alınan tedbirler zulüm altında tutulan Bulgar halkinin ekseriyeti tarafindan alaka ile takip ve tasvip edilmiştir.,"52

Balkan Paktı ile ilgili yapılan antlaşma her şeyden önce Türkiye'nin NATO üyeliğinden sonra en önemli snavlarından biriydi. İtalya ile sorunlarına rağmen Yugoslavya ve Yunanistan'1 bir noktada buluşturmak kolay değildi ve Türk dış politikası bunu başarmış oluyordu. Bir NATO üyesi olarak sorumluluklarını çekinmeden yerine getireceğini uluslararası alanda ve ABD nezdinde ispat etmiştir.

\section{Balkan İttifakı (9 Ăgustos 1954)}

Türkiye'nin öncülüğünde 28 Şubat 1953 tarihinde Türkiye, Yunanistan ve Yugoslavya arasında bir dostluk ve işbirliği adıyla antlaşma imzalanmış ve buna dayalı olarak bir Balkan Paktı kurulmuşsa da bu sadece bir başlangıçtı. Henüz bir Balkan İttifakı ortada yoktu. Balkanların geleceği ve güven ve barış için bundan sonrasında yapılan bu antlaşma çerçevesinde ilişkiler daha da geliştirilmeli ve daha farklı bir noktaya getirmeliydi. Nihayet üç devlet arasında antlaşma sonrasında antlaşmanın gereği olarak başlatılan yoğun ilişkiler sonuçta 9 Ağustos 1954 tarihinde Bled'de imzalanacak ve Balkan İttifakının kurulmasını sağlayacak antlaşmanın da ortaya çıkmasında önemi rol oynayacaktır. 28 Şubat 1953 tarihinde imzalanan Dostluk ve İşbirliği Antlaşması'ndan sonra üç devlet temsilcileri arasında karşılıklı ziyaretler yapılmış ve dışişleri bakanları bu antlaşma ile öngörülen ilk yıllık toplantılarını 7-11 Temmuz 1953 tarihinde Atina'da yapmışlardır.

\footnotetext{
51 Son Posta, 4 Mart 1953, s. 1.

${ }^{52}$ Son Posta, 4 Mart 1953, s. 7.
} 
Soğuk Savaş Sürecinde Komünizme Karşı Türkiye'nin Uluslararası Güvenlik ve Savunma İşbirlikleri Kurma Çabaları: Balkan Paktı ve İttifakı

$\mathrm{Bu}$ toplantıdan sonra yayınlanan resmî bildiride üç dışişleri bakanının dünya durumunu ve özellikle üç memleketin civarındaki durumu tetkik ettikleri bildirilmekte ve bu tetkikin ışığı altında üç memleketin dünya hadiselerinin gelişimi konularında tam bir görüş birliğine sahip oldukları görülmüştür. Uluslararası gerginliğin yatıştırılması ve sorunların halledilmesi amacı ile üç ülkenin ihtiyatlı kararlı ve uyanık hareketlerine devam etmelerine karar verilmiştir. ${ }^{53}$ Bildiride ayrıca şu noktalara da değinilmiştir:

1. İleride toplanacak konferansları hazırlamak ve işbirliği çerçevesine girecek sorunları incelemek üzere daimi bir sekreterlik kurulması.

2. Üç ülkenin Genelkurmaylarının üçlü askerî işbirliğinin ilerletilmesini temin edecek esasları tetkikle görevlendirilmesi.

3. Üç devlet arasında ekonomik işbirliği yollarını araştırmak üzere üçlü komite kurulmas1.

$\mathrm{Bu}$ bildiri ile kararlaştırılan askerî görüşmeler Kasım 1953'te Belgrad'da Mart 1954'te de Ankara'da yapılmış ve ortak savunma sorunları incelenmiştir. Bu görüşmelerden sonra yapılan açıklamalarda ortak savunma konularında geniş bir görüş birliğine varıldığ1 bildirilmektedir. Aynı şekilde üç devlet temsilcilerinin Şubat 1954'te yaptıkları toplantıda Belgrad'da devamlı bir sekreterliğin kurulması konusunda da görüş birliğine varılmıştır. ${ }^{54} 9$ Ağustos 1954'te Balkan İttifakı'na dair antlaşmanın imzalanışına kadar geçen süreçte üç devlet temsilcileri önemli çalışmalar gerçekleştirmişlerdir.

Balkan İttifakını ortaya çıkaran görüşmelerde 28 Haziran-5 Temmuz 1954'te Atina'da yapılan toplantı önemli adım teşkil etmiştir. Bu toplantıya katılan Türkiye, Yunanistan ve Yugoslavya temsilcileri toplant1 sonrasında tarafların tam bir görüş birliğine vardıkları ve Balkan İttifaknamesi ile ilgili projeyi hazırladıklarını açıklanmıştır. Hazırlanan

\footnotetext{
${ }^{53}$ Olaylarla Türk Dış Politikası, Cilt: I 1919-1973, s. 241.

${ }^{54}$ Olaylarla Türk Dış Politikası, Cilt: I 1919-1973, s. 240.
}

\section{5}

Güvenlik Stratejileri

Cilt: 17

Say1: 37 


\section{Ceyda TUNA KOCAOĞLU}

26

Güvenlik Stratejileri

Cilt: 17

Sayı: 37

Balkan İttifak projesi ilgili tarafların uzmanları tarafın parafe edildikten sonra ilgili hükümetlere gönderilmiştir. ${ }^{55}$

Balkan İttifakı ile ilgili gelişmeler Türk basını tarafından da desteklenmiştir. Dünya gazetesi yazarlarından A. İhsan Barlas tarafin "Balkan İttifakı ve Batı" başlığıyla kaleme alınmış olan bir yazıda ittifakın tereddüt etmeden kabul edilmesinden bahsedilmiştir. Barlas, yazısında, Balkan İttifakı projesi çalışmalarına ve önemine değindikten sonra konu ile ilgili farklı boyutlara dikkat çekmiştir. Kuzey Atlantik Teşkilatı Genel Sekreteri Lord İsmay'ın Londra ziyareti sırasında yaptığı basın toplantısında Balkan İttifakı ile ilgili olarak söylediği "Türkiye, Yugoslavya, Yunanistan askerî ittifakının Batı kuvvetine çok şey ilave edeceğini, bu cepheyi büyük ölçüde takviye eyleyeceği” ş̧eklindeki sözlerine ilaveten "Fakat bu paktın Italya ile sebep olabileceği herhangi siyasi bir ihtilafi hesaba katmiyorum" değerlendirmesine dikkat çeken Barlas, yazısında, bununla ilgili şu yorumu yapmıştır: "İtalya NATO çerçevesi içinde Türkiye ve Yunanistan'ın müttefikidir. Ayrica gerek bizimle, gerek Yunanistan'la sıkı münasebetler kurmuş anlaşmalar imzalamış olduğunu da biliyoruz. Trieste davast yüzünden Yugoslavya ile bir ihtilafi olduğu da bilinen bir şeydir. Fakat İtalya'yı Balkan İttifakı'nı daima sinirli bir yüzle karşılamağa sevk eden şey hakikat yalnı ve yalnı Trieste davası midır? Bizi bu suale sevk eden sebep, son günlerde Trieste meselesinin hal safhasina girmiş olduğu yolunda inanılır kaynaklardan gelen haberlerle, bizzat Mareşal Tito'nun söylediği sözlerdir. Yugoslavya Cumhurbaşkanı birkaç gün evvel Brioni adasındaki yazlık köşünde Sloven Cephesi adl teşekküle mensup Trieste temsilcilerinden mürekkep bir heyeti kabul etmistir. Heyet Triesteye döndükten sonra bir tebliğ neşreylemiş ve bunda Mareşal Tito'nun kendilerine Trieste meselesinde Italya ile Yugoslavya arasında hiç olmazsa muvakkat bir anlaşmaya varllması zaruri görülmüstür dediğini ilan etmiştir. ... Şu halde Yugoslavya meseleyi halle hazır bulunuyor. Demektir. ... Buna rağmen Lord İsmay'ın gösterdiği ihtiyat cidden dikkate değer. Bu ihtiraz kaydını

${ }^{55}$ Son Saat, 7 Temmuz 1954, s. 7. 
Soğuk Savaş Sürecinde Komünizme Karşı Türkiye'nin Uluslararası Güvenlik ve Savunma İşbirlikleri Kurma Çabaları: Balkan Paktı ve İttifakı

bir tarafa bırakalım ve Batı cephesini büyük ölçüde takviye edeceğini NATO'nun en yetkili şahsiyetinin de kabul ettiği ittifakı tereddütsüz imza edelim. Yürünecek yol budur". ${ }^{56}$

$\mathrm{Bu}$ arada Atina'da yapılan toplantıda ortaya çıkan Balkan İttifakı projesinin içeriği ile ilgili bazı bilgiler Türk basınında yer almıştır. Buna göre Balkan İttifakı projesi siyasi ve askerî olmak üzere iki kısımdan oluşuyordu. Siyasi kısımda üç dışişleri bakanı temmuz ayı içinde Bled'de yapacakları toplantıda NATO üyesi olan Türkiye ve Yunanistan'la bu teşkilat dışında bulunan Yugoslavya arasındaki irtibatın formülünü belirleyecekleri bilgisi yer alıyordu. Askerî kısımda ise üç kurmay heyeti tarafindan hazırlanmış olan raporun ittifak metnine ilave edildiği ve bu raporun Bulgaristan tarafindan meydana gelmesi muhtemel herhangi bir saldırı karşısında tarafların karşılıklı görevlerinden bahsettiği ifade ediliyordu. ${ }^{57}$

Balkan İttifakı ile ilgili olarak kaleme alınan hemen bütün yazılarda ittifakın önündeki en büyük meselenin Yugoslavya gibi NATO'ya dâhil olmayan bir ülke ile gerçekleştirecek olması ve bundan kaynaklanacak durumlar gösterilmiş buna rağmen aradaki sorunların halledilebileceği belirtilmiştir. Gerçekten de İttifakın önündeki en büyük engel NATO üyesi bir devlet olan İtalya ile NATO üyesi olmayan bir devlet olan Yugoslavya arasindaki Trieste sorununun henüz tam ve kesin bir şekle sokulmamış olmasıydı. Endişeler tamamen bu konuya yoğunlaşmıştır. ${ }^{58} \mathrm{Bu}$ durumu dikkate alan Türkiye 17 Temmuz 1954'te Yugoslavya'da yapılması kararlaştırılan toplantının da ertelenmesi talebinde bulunmuş ve bu talep olumlu karşılanmıştır. Türkiye NATO üyesi olamayan bir ülke konumundaki Yugoslavya ile ilgili NATO üyesi devletlerin hassasiyetlerine dikkat etmek mecburiyetindeydi. ${ }^{59}$ Ayrıca Yugoslavya, yapılması düşünülen ittifak ile Türkiye ve Yunanistan'a karşı yükleneceği taahhütlerden endişeliydi. Temel sorun da

\footnotetext{
${ }^{56}$ Dünya, 7 Temmuz 1954, s. 3.

${ }^{57}$ Dünya, 9 Temmuz 1954, s. 3.

${ }^{58}$ Son Telgraf, 10 Temmuz 1954, s. 3.

59 Son Posta, 15 Temmuz 1954, s. 7.
} 


\section{Ceyda TUNA KOCAOĞLU}

28

Güvenlik Stratejileri

Cilt: 17

Sayı: 37

buydu. Türkiye ve Yunanistan doğrudan bir saldırıya uğradığı takdirde Yugoslavya bu ülkelerin yardımına koşmayı kabul ediyordu. Ancak Yugoslavya, bu memleketlerin NATO'ya dâhil müttefiklerinden birine yapılacak bir saldırı sonucunda çıkacak bir savaşta aynı yardımı yapmayı kabul etmemekteydi. Bu durumda Türkiye ve Yunanistan hangi şartlar altında olursa olsun Yugoslavya'yı yardım taahhüdü altına sokma konusunda Belgrad'a gereken baskıları yapmak gibi bir durumla karşı karşıyaydılar. $\mathrm{Bu}$ anlaşmazlık aslında Atina'daki toplantının da ana konusunu teşkil etmiş ancak sorunun büyümesine ve dişarıya yansımamasına önem göstermişlerdir. Türkiye ve Yunanistan, Atlantik Paktı devletleriyle Sovyet Bloğu arasında çıkacak herhangi bir çatışmada Yugoslavya'nın kendileriyle birlikte savaşmayı kabul etmediği müddetçe imzalanacak askerî bir ittifakın bir etkisinin olamayacağını kesinlikle biliyorlardı. Türkiye uzun zamandır Yugoslavya dışarıda bırakıldığ takdirde Atlantik İttifakı'nın eksik kalacağı noktasında da ısrar ediyor ve Belgrad'in NATO'ya doğrudan doğruya kabulünü istiyordu. Bu mümkün olmayınca da Türkiye ve Yunanistan bir askerî ittifakla yapmak istediler bu ise kısa sürede bazı sorunların ortaya çıkmasına neden olmuştur. Türkiye Mareşal Tito'nun Nisan 1954'te Ankara'ya yaptığı ziyarette Yugoslavya'nın Batı Savunma sistemine girmek konusunda hazır olduğunu açıkça söylediği halde şimdi neden böyle bir tavır geliştirdiği konusunda endişe duymaktaydı. ${ }^{60} 17$ Temmuz'da yapılacağı kararlaştırılan görüşmelerin Türkiye'nin, yukarıda bahsi geçen endişelerden dolayı, talebiyle ertelendiği görüşü hemen Türkiye'deki ulusal basının ortak düşüncesi haline gelmiştir. Son Posta gazetesi de söz konusu erteleme ile ilgili aynı düşünceleri paylaşmıştır. ${ }^{61}$ Erteleme ile

\footnotetext{
${ }^{60}$ Dünya, 14 Temmuz 1954, s.3.

${ }^{61}$ Üçlü Askerî İttifakın tehiri meselesi ile ilgili olarak Son Posta gazetesinde şu bilgilere yer verilmiştir: "Bled toplantısl, Türkiye'nin talebi üzerine geri birakıldı̆̆ bilinmektedir. Türkiye, muahedeyi imzalamadan evvel NATO'ya mensup bütün devletlerin Balkan Ittifakın kayıtsız şartsiz kabul etmelerini istemektedir. NATO'ya mensup bazı devletlerin Balkan Paktının bazı veçheleri hakkında tereddütler izhar ettikleri anlaşılmaktadır. Bilhassa şu cihet üzerinde durulmuştur: Türkiye ve Yunanistan'ın askerî alanda NATO'ya mensup diğer herhangi bir memlekete yardıma çağrlmaları halinde
} 
Soğuk Savaş Sürecinde Komünizme Karşı Türkiye'nin Uluslararası Güvenlik ve Savunma İşbirlikleri Kurma Çabaları: Balkan Paktı ve İttifakı

ilgili Son Saat gazetesinde ise "İttifaknamenin imzası için yapılacak toplantının geri bırakılması bir sürpriz teşkil etmemektedir. NATO azast olmayan Yugoslavya'nın durumu üzerinde NATO memleketlerini tatmin edici bir hal şekli tesbit edilmemesi bu neticeyi doğurmuştur. Trieste ihtilafinın henüz muallakta bulunması da NATO azası memleketleri bu mevzu üzerinde düşünceye sev etmiş ve ittifaknamenin imzasının geri bırakılması zaruri kilan sebepler ki; başta Yugoslavya'nın durumu gelmektedir, ittifakname metninin NATO'da tetkiki sirasinda kati şekilde ortaya çıkmıştır" değerlendirmesi yapılmıştır. ${ }^{62}$

Atina toplantısı sonrasında ortaya çıkan bu sorunlara rağmen temmuz ayı sonlarında üç devletin temsilcilerinin Yugoslavya'da bir araya gelecekleri ve sorunları çözüme kavuşturarak Balkan İttifakı'nı imzalayacakları kısa sürede netlik kazanmıştır. Çünkü başta $A B D$ olmak üzere Batılı devletler süreci yakından takip etmekteydiler ve Balkan askerî ittifakına büyük önem veriyorlardı. Gerçekten de bakıldığında Balkan askerî ittifakı kuvvet bakımından hiç de küçümsenecek bir şey değildi. Balkan İttifakı Adriyatik’ten Kafkaslara kadar 4500 kilometrelik bir kısmın savunmasını üzerine alacaktı. Barış zamanında 800.000 askerin müdafaa edeceği bu hat savaş sırasında iki buçuk milyon askeri bulabilecekti. İttifakın elinde ayrıca, birinci sınıf 16 bin uçak bulunuyordu. ${ }^{63} \mathrm{Bu}$ öneminden dolayı taraflar var olan bütün sorunlara rağmen ittifakın bir an önce imzalanmasını istiyorlardı. Nihayet 16 Temmuz'da Yunan Başbakanı Mareşal Papagos, üç devlet arasındaki askerî ittifak antlaşmasının bir an önce imzalanmasını sağlamak amacıyla Başbakan Adnan Menderes ve Mareşal Tito'ya birer mesaj göndermiştir. ${ }^{64}$ Yunan Başbakanının mesajına gecikmeden cevap veren Tito, ittifakın gecikmeden bir an evvel imzasından yana

Yugoslavya'nın ittihaz edeceği vaziyet muahedede tasrih edilmemiştir. Buradaki yetkili diplomatlar bu hususun pakta resmen ithalinin kolay olmadiğını müdriktirler”. Son Posta, 16 Temmuz 1954, s. 7.

${ }^{62}$ Son Saat, 16 Temmuz 1954, s. 5.

${ }^{63}$ Son Telgraf, 13 Temmuz 1954, s. 3.

${ }^{64}$ Son Posta, 7 Temmuz 1954, s. 7. 

olduğunu açık bir dille ifade etmiştir. ${ }^{65}$ Adnan Menderes de cevabında Üçlü Balkan İttifakının imzalanması için kararlaştırılan Türkiye, Yunanistan ve Yugoslavya Dışişleri Bakanları konferansının bir an evvel yapılması konusunda Yunan Başvekilin düşüncelerini tamamen kabul ettiklerini ifade etmiştir. ${ }^{66} \mathrm{Bu}$ gelişmelerden hemen sonra üç devlet temsilcilerinin bir araya gelerek bir an önce toplantı tarihinin netleştirileceği ve muhtemelen ağustos ayının ilk on günü içerisinde Balkan İttifakı antlaşmasının imzalanacağı söylentileri basında yer almıştır. $^{67} \mathrm{Bu}$ arada Batı kamuoyunda çıkan bazı haberlerde de Türkiye'den bahsediliyor özellikle son zamanlarda Batı'nın güvenliği için Türkiye'nin daha önemli hale geldiği söyleniyordu. Nihayet İsviçre basınında Türkiye'nin önemli ile ilgili olarak "Batının Savunmasında Türkiye'nin Rolü' başlığıyla kaleme alınan bir yazıda Türkiye'nin son zamanlarda izlediği aktif dış politika ve özellikle Balkanlarda kurmaya çalıştığı savunma ittifakı etraflı bir şekilde ele alınmıştır. ${ }^{68}$ Ağustos ayı başlarında bir süredir Balkan İttifakı projesi üzerinde yürüttüğü incelemelerini tamamlayan NATO projeyi kabul etmiştir. ${ }^{69}$ Bu gelişmeler üzerine bir taraftan Yugoslavya'nın İtalya ile sorunları büyük ölçüde çözmüş olması, diğer yandan NATO'nun söz konusu projeyi onaylaması ve ABD'nin projeye verdiği önem ve Yunanistan Başbakanının taraflara yaptığı çağrı üzerine ağustos başlarında üç devlet dışişleri bakanının Balkan İttifakı'nı imzalamak üzere Yugoslavya'ya hareket etmelerine antlaşmanın imzalanması için gerekli hazırlıkların başlatılmasını beraberinde getirmiştir. Bu çerçevede Türk Dışş̧leri Bakanı Fuat Köprülü de 3 Ağustos akşamı Belgrad'a hareket etmiştir. Antlaşmanın imzalanması için ilk etapta kararlaştırılan tarih ise 6 Ağustos olarak belirlenmiştir. $^{70}$ Fuat Köprülü Belgrad'a hareketinden önce basına verdiği beyanatında imzalanacak antlaşmanın Balkanların savunması

\footnotetext{
${ }^{65}$ Son Telgraf, 19 Temmuz 1954, s. 3.

${ }^{66}$ Dünya, 24 Temmuz 1954, s. 3.

${ }^{67}$ Son Posta, 21 Temmuz 1954, s. 7; Son Posta, 24 Temmuz 1954, s. 7.

${ }^{68}$ Son Saat, 28 Temmuz 1954, s. 5.

${ }^{69}$ Son Saat, 3 Ağustos 1954, s. 5.

${ }^{70}$ Son Posta, 4 Ağustos 1954, s. 3.
} 
Soğuk Savaş Sürecinde Komünizme Karşı Türkiye'nin Uluslararası Güvenlik ve Savunma İşbirlikleri Kurma Çabaları: Balkan Paktı ve İttifakı

için büyük özem arz ettiğini söylemiştir. ${ }^{71} \mathrm{Bu}$ arada basında Balkan İttifakı'na İtalya'nın da katılabileceği haberleri de yer almıştır. ${ }^{72}$ Ayrıca Batı kamuoyu da imzalanacak bir Balkan İttifakını oldukça önemsiyordu. İngiliz gazetelerinden Observer, Balkan İttifakı ile ilgili olarak doğudaki Batı savunmasının kilit noktasının Türkiye olduğuna dikkat çekerek 20 milyonluk bir memleketin bu kadar önemli ve ağır bir görevi başarması için sağlam ve kuvvetli müttefikleri bulması gereğini vurguluyor ve şu değerlendirmeyi yapıyordu: "Bu sebepledir ki, Türkiye Yugoslavya ve Yunanistan arasinda akdolunacak Balkan Ittifakı'nın Batı stratejisi bakımından büyük ehemmiyeti vardır. Türkiye, doğuda Pakistan ve Iran'ı müttefik yapmă̆a çalışmaktadır. Kanal bölgesinin yerini tutan Orta Doğu'daki Batı savuma tertibatının esasını teșkil eden bu kuzey dizisi stratejisinin mümkün olduğu kadar erken bir zamanda inşası lazımdır". ${ }^{73}$ Balkan İttifakının imzalanacak olması Türk kamuoyunda da geniş yer bulmuş ve Türkiye'nin çabalarıyla gerçekleşen İttifak Antlaşmasının önemi etraflıca ele alınarak önemli değerlendirmeler yapılmıştır. ${ }^{74}$

Balkan İttifakı ile ilgili görüşmeler üç devletin dışişleri bakanlarının 6 Ağustos'ta Bled şehrinde bir araya gelmeleriyle başlamıştır. İki gün

\footnotetext{
${ }^{71}$ Fuat Köprülü şunları söylemiştir: "1953 te Ankara'da imzalanan üçlü dostluk ve işbirliği antlaşmasinın ilk merhalesini teşkil ettiği ve o günden beri vakit kaybetmeden ve aynı zamanda icabeden bütün temkin ile adım adım hazırlanan üçlü Balkan İtifakı'nın üç müttefik hariciye vekillerinin Bled'de yapacakları toplantının aynı zamanda ittifakın imzalanmasına da müncer olacağını düşünmekle bahtiyarlık hissediyorum. Arz ettiği ehemmiyete ve mümasil hallere nisbet ile cidden çabuk olgunlaştırlmış olan bu ittifaknamenin kısa hazırlık devresinde türlü dedikodular çıkarıldl. Biz bunlardan dolayı telaşlanmadan işimize devam ettik. Zira hadisatın mantığının bizi behemehâl hedefimize götüreceğinden emindik. Balkan İttifakının sulhun vikayesi ve emniyetin sağlamlaşması bakımından daima hareket ile terviç ettiğimiz deliksiz bir müşterek emniyet cephesinin kurulması hususunda ne kadar büyük bir kıymet ifade ettiği bugün artık bir bedahet haline gelmiş bulunuyor. Bled'e hür dünya için çok hayırlı bir eserin vücuda getirilecek olmasının verdiği inşirah ve iftihar ile gitmekteyiz”. Bkz: Son Posta, 5 Ağustos 1954, s. 7.

${ }^{72}$ Son Saat, 6 Ağustos 1954, s. 5.

${ }^{73}$ Dünya, 5 Ağustos 1954, s. 3.

${ }^{74}$ Son Telgraf, 6 Ağustos 1954, s. 3.
}

\section{1}

Güvenlik Stratejileri

Cilt: 17

Say1: 37 
süren görüşmeler 7 Ağustos akşamı son tamamlanarak taraflar 9 Ağustos günü Balkan İttifakının imzalanmasına karar vermişlerdir. ${ }^{75}$ Balkan

Güvenlik Stratejileri

Cilt: 17

Sayı: 37 İttifakı ile ilgili antlaşma belirlendiği şekilde 9 Ağustos 1954 tarihinde Yugoslavya'nın Bled şehrinde Türkiye Yugoslavya ve Yunanistan arasında imza edilmiştir. 14 maddeden oluşan bu antlaşma ile aynı üç devlet arasında 28 Şubat 1953 tarihinde imzalanmış olan ve Balkan Paktı'nın resmen kuruluşunu gerçekleştiren Dostluk ve İşbirliği Antlaşması bir askerî savunma sistemi olan bir ittifaka dönüşmüş oluyordu. ${ }^{76}$ Antlaşmanın 1. Maddesine göre taraflar, tüm uluslararası anlaşmazlıkları barışçı yollarla çözmeyi ve uluslararası ilişkilerde Birleşmiş Milletler Antlaşması'nın amaçlarıyla bağdaşmayacak herhangi bir şekilde tehdit ya da kuvvete başvurmaktan kaçınmayı yükümleniyorlardı. Bir saldırı halinde tarafların alacakları önlemleri belirleyen 2. madde de ise, taraflardan birine ya da birkaçına karşı ülkelerinin herhangi bir yerine yönelik olarak girişilecek her silahlı saldırıyı tüm bağıtlı taraflara yöneltilmiş bir saldırı saymak ve silahlı kuvvet kullanımı da kapsam içine girmek üzere etkin bir savunma için gerekli görecekleri tüm önlemleri birlikte kararlaştırarak almak ve saldırıya uğrayan taraf ya da taraflara gecikmeksizin tek başına ve ortaklaşa yardım etmek konusunda anlaşmışlardır. Antlaşmanın bir diğer maddesi olan 7. maddede de, tarafların silahlı bir saldırıya uğradıktan sonra alacakları meşru savunma önlemlerini, durumu BM Güvenlik Konseyine bildirdikten ve Konsey gerekli önlemleri fiilen aldıktan sonra sona erdirmeleri gerektiğini belirtmektedir. Dolayısıyla Kuzey Atlantik Antlaşması'yla aynı 1934 Balkan Paktı'ndan çok daha geniş bir düzenleme söz konusudur. Bu antlaşma ayrıca, tarafların dışişleri bakanlarının yılda iki kez düzenli bir biçimde toplanacakları bir Sürekli Konsey oluşturulması ve bu Sürekli Konsey toplanamadığ zamanlarda görevlerini Ankara Antlaşması Sürekli Sekreterliği aracılığıyla yerine getirmesi kararlaştırılmıştır. 11. madde ile de 28 Şubat 1953'te Ankara'da imzalanan Dostluk ve İşbirliği Antlaşması'nın

\footnotetext{
${ }^{75}$ Son Posta, 8 Ağustos 1954, s. 7.

${ }^{76}$ Türk Dış Politikası, Baskın Oran,(ed.), s. 590.
} 
Soğuk Savaş Sürecinde Komünizme Karşı Türkiye'nin Uluslararası Güvenlik ve Savunma İşbirlikleri Kurma Çabaları: Balkan Paktı ve İttifakı

yürürlükte kalacağı bildirilmiştir. Bu itibarla Bled Antlaşması Ankara Antlaşması'nın etkinleştirilmesi ve bir ittifak biçimine sokulması olarak yorumlanabilir. ${ }^{77}$

Bled Antlaşması'na Türkiye adına imza koyan Dıșişleri Bakanı Fuat Köprülü, yurda döndükten sonra Anadolu Ajansına verdiği beyanatında düşüncelerini şu ifadelerle ortaya koymuştur: "Bled'de imzalanan ve 'ittifak, siyasi işbirliği ve karşıllklı yardım andlaşması' ismini taşlyan ve tarihe klsaca 'Bled Itttifakl' adiyla geçecek olan bu antlaşmanın metni daha imzalandığ gün olduğu gibi ilan edildiği cihetle, muhtevası hakkında ayrıca tafsilat vermeğe lüzum görmüyorum. Bu andlaşmanin kaymet ve ehemmiyeti hakkinda fikir edinmek isteyenlerin cihan matbuatında bunun hakkında çıkan yazılara bir göz gezdirmesi kâfidir. Hakiki sulhsever memleketlerde bu andlaşma sulhun korunmast ve emniyetin sağlamlaşmast yolunda mühim bir eser olarak selamlanmıștır. Milletlerin haklarina ve toprak bütünlüklerine riayet esasina müstenid hakiki bir sulha taraftar olamayanları bu andlaşmayı ayn memnuniyetle karşılamaları bittabi beklenemez. Bu da anlaşmanin kaymetinin ayrica bir delili demektir. Bu andlaşma hakiki sulhun teessüsü için bütün imkânlart ile çalışmaya azmetmiş bulunan ve hakiki sulhun vikayesinin ancak tecavüzün karlı bir iş teşkil edemeyeceğini fiilen ispat edebilecek derecede sulhsever devletlerin kuvvetli ve mütesanit bulunmaları gerektiğine kanaat getirmiş olan üç hüsnüniyet sahibi milletin eseridir. Bu itibarla tam manasiyla bir realist görüş neticesidir. ",78

Bled Antlaşması Türk basınında oldukça önemli bir antlaşma ve Türkiye'nin başarısı olarak değerlendirilmiştir. Antlaşma ile ilgili olarak Dünya gazetesinde yer alan bir analiz yazısında Antlaşma ile ilgili şu ilginç yorum yapılmıştır: "Andlaşmanın cihanşümul bir manast vardır ki, belirtmeden geçemeyeceğiz: Ekonomik ve sosyal doktrinleri birbirinden tamamen ayrı olan Yugoslavya ile Türkiye ve Yunanistan'ın siyasi, askerî, mali ve kültürel bütün veçhelere şamil bir ittifak andlaşmastyla

\footnotetext{
${ }^{77}$ Türk Dıș Politikası, Baskın Oran, (ed.), s. 590-591.

${ }^{78}$ Son Posta, 13 Ağustos 1954, s.7.
} 
Güvenlik Stratejileri

Cilt: 17

Sayı: 37

bir karşıllklı yardım ahdiyle bağlanmaları son günlerin büyük bir davasını halletmiştir: Barış içinde yan yana yaşamak kabil midir? suali 9 A ğustostan itibaren abes bir mevzu haline gelmiştir". ${ }^{79}$ Antlaşma Türkiye ve taraf devletlerin kamuoylarında olduğu kadar başta Amerika Birleşik Devletleri olmak üzere Batı kamuoyunda da önemli bir gelişme olarak görülmüştür. ABD basınının hemen tamamı antlaşmayı komünizme karşı kazanılmış büyük bir zafer olarak görmüşlerdir. ${ }^{80}$

Balkan İttifakı Sürekli Konseyi ilk toplantısını Ankara'da yaptı ve toplantı sonunda 2 Mart 1955'te Sürekli Meclisi kuran bir antlaşma imzaland1. Üye devletlerin ulusal meclislerinin her birinin kendi içinden seçeceği 20 üyeden oluşacak sürekli meclisin görevi her alanda işbirliğini geliştirmeye yardım edecek tüm olanakları araştırmaktı. 19 Mart 1955'te de posta haberleşmesiyle ilgili bir antlaşma imzalayan Sürekli Konsey'in bir daha toplanması mümkün olmamıştır. Balkan İttifakı, SSCB'den tehdit algılayan ve aralarında sorun bulunmayan üç balkan ülkesinin Batı'dan aldıkları destekle oluşturdukları bir savunma mekanizmasıydı. Oluşmasına neden olan koşullar ortadan kalktığında da işlevini yitireceği gayet açık bir durumdu. Nitekim daha antlaşma imzalandığı sıralarda bile şartlar değişmeye başlamıştı. 1953'te Stalin'in ölümü, Sovyet dış politikasında yumuşamanın başlangıcı oldu ve bu politika değişikliği Moskova'nın Balkan ülkeleriyle olan ilişkilerine de yansımışır. Moskova'nın Yugoslavya'ya uyguladığı ekonomik yaptırımların kaldırılması, diplomatik ilişkileri düzeltmesi bunun işaretleriydi. 1955'ten itibaren Sovyetlerin yeniden Yugoslavya'y1 Bat1 etkisinden çıkarmaya çalışmaları Yugoslavya'nın Balkan İttifakına olan ilgisini azaltmış ve giderek ittifakın etkisiz hale dönüşmesine neden olmuştur. ${ }^{81} \mathrm{Bu}$ gelişmeler Balkan İttifakının kısa süreli olmasında önemli rol oynamıştır.

\footnotetext{
${ }^{79}$ Dünya, 13 Ağustos 1954, s. 3.

${ }^{80}$ Son Posta, 13 Ağustos 1954, s.7.

${ }^{81}$ Türk Dış Politikası, Baskın Oran,(ed.), s. 591.
} 
Soğuk Savaş Sürecinde Komünizme Karşı Türkiye'nin Uluslararası Güvenlik ve Savunma İşbirlikleri Kurma Çabaları: Balkan Paktı ve İttifakı

\section{Sonuç}

1945'te II. Dünya Savaşı'nın sona ermesiyle birlikte uluslararası ortam yeni bir şekil almıştır. Tarihte ilk kez uluslararası ilişkiler ideolojik bir temel üzerinden iki kutuplu olarak yeniden belirlenmiştir. $\mathrm{Bu}$ durumda başını ABD'nin çektiği liberal blok ile başını Sovyet Rusya'nın çektiği komünist blok arasında uluslararası ilişkiler yeniden şekillenmiştir. Böyle bir ortamda devletler için en temel sorun hangi blokta yer alınacak olmasıydı. Nihayet Türkiye II. Dünya Savaşı yıllarında her ne kadar dikkatli ve tarafsız kalma politikası izlemişse de uluslararası ortamın aldığı bu yeni şekil karşısında fazla bir tereddüt göstermeden Batı Bloku'nda olduğunu dış politikada gösterdiği hızlı ve keskin dönüşümle ispat etmeye çalışmıştır. NATO'nun kuruluşunun hemen ardından hiç çekinmeden kararlılıkla üye olma yönündeki adımları bunu net bir şekilde göstermiştir. Nitekim 1952'de Yunanistan ile birlikte NATO'ya üye olarak girmeleri bu ülkeler için yeni sorumlulukları da beraberinde getirmiştir. Nihayet 1953-1954 tarihlerinde büyük oranda Türkiye'nin çabalarıyla gerçekleşen Balkan Paktı ve İttifakı bunun en somut örneği olsa gerektir. Bir taraftan dâhil olduğu NATO üyeliği diğer taraftan ABD ile iyi ilişkiler kurmak ve bu suretle başta ekonomik olmak üzere siyasi alanda desteğini sağlamak niyetindeki yeni Türk dış politikası bu çerçevede bu niyetini gerçekleştirebileceği en verimli bölgeyi de iyi seçmiştir. Savaş boyunca önemli bir kısmı Sovyetler tarafından uydu devletler haline getirilmiş olan Balkan coğrafyas1, komünizm tehlikesinin en fazla hissedildiği ve Batı bloğu için en büyük tehlike olarak ortada duruyordu ve bir şeylerin yapılaması gerekiyordu. Bir süredir Türkiye'nin Akdeniz ve Orta Doğu'da bölgesel oluşmalar yönündeki gayretlerini yakından bilen gören ve takip eden $A B D$ ve NATO üyeliği Türkiye'nin kendisini ispat etmesi için önemli sorumluluklar yüklüyordu. İşte bu gerekçeler gerek 1953'te önce Dostluk ve İşbirliği, 1954'te de bir İttifak antlaşmasının ortaya çıkmasında önemli rol oynamıştır. Gerçekten de her iki antlaşma ve bu antlaşmaların oluşum sürecinde ortaya çıkan sorunların halledilmesinde Türk Dışişleri büyük beceri ve çaba göstermiştir. Bu çabaların sonucunda ortaya çıkan savunma sistemi ise Batı bloğu mensubu bulunan bütün devletleri hem 
36

Güvenlik Stratejileri

Cilt: 17

Sayı: 37 rahatlatmış hem de Türkiye'ye olan güveni arttırmıştır. Türkiye'nin bu başarısı ise iç politikada mevcut iktidarın elini güçlendirmiştir.

\section{Summary}

World politics entered a new era after the Second World War. Being allies during the war, the United States and the Soviet Union became implacable enemies of each other. The Soviet Union was able to establish a political order based on communism in Central and Eastern Europe during the war and formed satellite states particularly in Eastern Europe. As a result, the Soviet Union became the chief enemy and the main threat for the capitalist world. International politics had to develop under the monopoly of these two super powers in the Cold War era. The struggle between the USA, leader of the capitalist world, and the Soviet Union, leader of the communist world, forced the rest of the states choose their side. Accordingly, the struggle against the Soviet Union and communism initiated by the USA immediately after the war had its effects worldwide, particularly in regions under the direct threat of communism. As a result, struggle against communism became the primary problem of political life in many countries. In this regard, the struggle against communism in the Balkans, the Middle East, Iran and Turkey became the main determinant in domestic and foreign policies. Turkey, which was able to remain non-belligerent during the Second World War, took its position by the Western Powers led by the USA without delay in view of the new form of international relations. Thus, Turkey embarked on an effective struggle against communism both at home and at the international level. Turkey initiated an effective and systematic struggle against communism at home particularly from 1949 on and after participating the NATO in 1952, it began to pursue an effective foreign policy against communism. Consequently, Turkey received approval from the USA and the Western public. One of the most important milestones of this struggle by Turkey is the Balkan Pact signed by Turkey, Greece and Yugoslavia on 28 February 1953 and the Balkan Alliance signed on 9 August 1954. Turkey was able to establish a security and defense zone against communism in the Balkans between 1952 and 1955 thanks to the effective diplomacy it pursued from the end of 1952 onwards. Turkey achieved an important 
Soğuk Savaş Sürecinde Komünizme Karşı Türkiye'nin Uluslararası Güvenlik ve Savunma İşbirlikleri Kurma Çabaları: Balkan Paktı ve İttifakı

goal in the international struggle against communism by being able to bring Greece, a NATO member, and Yugoslavia, a socialist country ideologically close to the Soviet Union, into the same pact and alliance. These efforts of Turkey increased its importance as a fresh member of the NATO and promoted Turkey as the most significant and effective ally of the Western Block in the Middle East.

\section{Kaynakça \\ Kitaplar \\ ARMAOĞLU, Fahir, 20. Yüzyıl Siyasi Tarihi 1914-1980,Cilt:I; Türkiye İş Bankası} Yayınları, Ankara, 1991.

BEST, Antony, HANHIMAKI, Jussi M., MAIOLO, Joseph A., SCHULZE, Kirsten E., 20.Yüzyılın Uluslararası Tarihi, (Çev: Taciser Ulaş Belge), Siyasal Kitabevi, Ankara, 2012.

BURUMA, Ian, Slfir Yllı (1945'in Tarihi), Çev: Nurettin Elhüseyni, Yap1 Kredi Yayınlar1, İstanbul, 2013.

GENCER, Özcan “Ellili Yıllarda Dış Politika”, Türkiye'nin 1950'li Yılları, Mete Kaan Kaynar,(ed.), İletişim yayınları, İstanbul, 2015.

JUDT, Tony, Savaş Sonrası: 1945 Sonrası Avrupa Tarihi, Yapı Kredi Yayınları, İstanbul, 2009.

ÖKSÜZ, Hikmet, "Türkiye Cumhuriyeti Devleti'nin Balkan Politikası" , Türk Dış Politikası: Cumhuriyet Dönemi, 2. Kitap, Mustafa Bıyıkl,(ed.), Gökkubbe Yayınları, İstanbul, 2008.

ROBERTS, J.M. Avrupa Tarihi, (Çev: Fethi Aytuna), İnkılap yayınları, İstanbul, 2015. ROBERTS, J.M. Yirminci Yüzyıl Tarihi, (Çev: Sinem Gül), Dost Yayınları, Ankara, 2003.

Olaylarla Türk Dış Politikası, Cilt: I 1919-1973, Haz. Mehmet Gönlübol, Cem Sar, AÜ Siyasal Bilgiler Fak Yayınlar1, Ankara, 1987.

Türk Dış Politikası, Cilt : I 1919-1980, Baskın Oran (ed.), İletişim Yayınları, İstanbul, 2002. UÇAROL, Rifat, Siyasi Tarih (1789-1994),Filiz Kitabevi, İstanbul, 1995.

\section{Gazeteler}

Dünya, 7 Temmuz 1954 tarihli gazete haberi.

Dünya, 9 Temmuz 1954 tarihli gazete haberi.

Dünya, 14 Temmuz 1954 tarihli gazete haberi.

Dünya, 24 Temmuz 1954 tarihli gazete haberi.

Dünya, 5 Ağustos 1954 tarihli gazete haberi.

Dünya, 13 Ağustos 1954 tarihli gazete haberi.

Son Posta, 1 Ocak 1953 tarihli gazete haberi.

Son Posta, 3 Ocak 1953 tarihli gazete haberi.

Son Posta, 11 Ocak 1953 tarihli gazete haberi.

Güvenlik Stratejileri

Cilt: 17

Say1: 37 


\section{Ceyda TUNA KOCAOĞLU}

38

Güvenlik

Stratejileri

Cilt: 17

Sayı: 37
Son Posta, 12 Ocak 1953 tarihli gazete haberi. Son Posta, 13 Ocak 1953 tarihli gazete haberi. Son Posta, 16 Ocak 1953 tarihli gazete haberi. Son Posta, 17 Ocak 1953 tarihli gazete haberi. Son Posta, 19 Ocak 1953 tarihli gazete haberi. Son Posta, 21 Ocak 1953 tarihli gazete haberi. Son Posta, 22 Ocak 1953 tarihli gazete haberi. Son Posta, 23 Ocak 1953 tarihli gazete haberi. Son Posta, 24 Ocak 1953 tarihli gazete haberi. Son Posta, 25 Ocak 1953 tarihli gazete haberi. Son Posta, 26 Ocak 1953 tarihli gazete haberi. Son Posta, 27 Ocak 1953 tarihli gazete haberi. Son Posta, 28 Ocak 1953 tarihli gazete haberi. Son Posta, 29 Ocak 1953 tarihli gazete haberi. Son Posta, 1 Şubat 1953 tarihli gazete haberi. Son Posta, 4 Şubat 1953 tarihli gazete haberi. Son Posta, 7 Şubat 1953 tarihli gazete haberi. Son Posta, 8 Şubat 1953 tarihli gazete haberi. Son Posta, 15 Şubat 1953 tarihli gazete haberi. Son Posta, 16 Şubat 1953 tarihli gazete haberi. Son Posta, 1 Mart 1953 tarihli gazete haberi. Son Posta, 4 Mart 1953 tarihli gazete haberi. Son Posta, 8 Mart 1953 tarihli gazete haberi. Son Posta, 7 Temmuz 1954 tarihli gazete haberi. Son Posta, 15 Temmuz 1954 tarihli gazete haberi. Son Posta, 16 Temmuz 1954 tarihli gazete haberi. Son Posta, 21 Temmuz 1954 tarihli gazete haberi. Son Posta, 24 Temmuz 1954 tarihli gazete haberi. Son Posta, 4 Ağustos 1954 tarihli gazete haberi. Son Posta, 5 Ağustos 1954 tarihli gazete haberi. Son Posta, 8 Ağustos 1954 tarihli gazete haberi. Son Posta, 13 Ağustos 1954 tarihli gazete haberi. Son Saat, 7 Temmuz 1954 tarihli gazete haberi. Son Saat, 28 Temmuz 1954 tarihli gazete haberi. Son Saat, 3 Ağustos 1954 tarihli gazete haberi. Son Saat, 6 Ağustos 1954 tarihli gazete haberi. Son Telgraf, 10 Temmuz 1954 tarihli gazete haberi. Son Telgraf, 13 Temmuz 1954 tarihli gazete haberi. Son Telgraf, 19 Temmuz 1954 tarihli gazete haberi. Son Telgraf, 6 Ağustos 1954 tarihli gazete haberi. The Times, Jun 01, 1946, Issue: 50467 tarihli gazete haberi. 